Taubenheim $\mathrm{J}^{1,2}$, Willoweit-Ohl $\mathrm{D}^{2}$, Knop $\mathbf{M}^{2}$, Franzenburg $\mathrm{S}^{3}$, He $\mathrm{J}^{2}$, Bosch TCG ${ }^{2}$,

\title{
Fraune $\mathbf{S}^{1,2}$
}

$9 \quad{ }^{1} \mathrm{HHU}$ Düsseldorf, Institute of Zoology and Organismic Interactions, 40225 Düsseldorf,

10 Germany

$11{ }^{2} \mathrm{CAU}$ Kiel, Zoological Institute, 24118 Kiel, Germany

$12{ }^{3} \mathrm{CAU}$ Kiel, Institute of Clinical Molecular Biology, 24118 Kiel, Germany

13

14

15

16

17

18 Corresponding author: fraune@hhu.de 


\section{Abstract}

22 Animal development has traditionally been viewed as an autonomous process directed by

23 the host genome. But in many animals biotic and abiotic cues, like temperature and bacterial 24 colonizers, provide signals for multiple developmental steps. Hydra offers unique features to 25 encode these complex interactions of developmental processes with biotic and abiotic 26 factors. Here, we used the model animal Hydra to investigate the impact of bacterial 27 colonizers and temperature on the pattern formation process. In Hydra, formation of the head 28 organizer involves the canonical Wnt pathway. Treatment with alsterpaullone (ALP) results in 29 acquiring characteristics of the head organizer in the body column. Intriguingly, germ-free 30 Hydra polyps are significantly more sensitive to ALP compared to control polyps. In addition 31 to microbes, $\beta$-catenin dependent pattern formation is also affected by temperature. Gene 32 expression analyses led to the identification of two small secreted peptides, named Eco1 and 33 Eco2, being upregulated in the response to both, Curvibacter sp, the main bacterial colonizer 34 of Hydra, and low temperatures. Loss-of function experiments revealed that Eco peptides are 35 involved in the regulation of pattern formation and have an antagonistic function to Wnt 36 signaling in Hydra. 


\section{Introduction}

39 Organisms develop in a specific environment, which is recognized and integrated into

40 developmental programs influencing the phenotype and fitness of an individual. Thereby,

41 environmental factors influencing the developmental processes are very diverse like

42 temperature (1), oxygen levels (2), social interaction $(3,4)$ or the associated microbiome (5).

43 Adjusting the developmental programs to environmental conditions directly translate into the

44 fitness of an individual and has impact on the evolution (6). The field of Ecological

45 Evolutionary Developmental (Eco-Evo-Devo) Biology integrates these three factors into a

46 theoretical framework $(7,8)$.

47 Numerous studies explore the effect of temperature on phenotypic differences and the 48 impact on developmental processes (9-12). However, whether the effect is caused by a 49 mere altered chemical reaction norm or whether temperature is actively sensed and 50 developmental programs are adjusted accordingly, is still under debate. There are evidences

51 for both scenarios $(11,13)$ and they might not exclude each other.

52 Similarly, the associated bacteria of an organism have been shown to affect developmental 53 processes of the host (14). They can drive the first cleavage and determine the anterior54 posterior orientation of the fertilized egg of nematodes (15), induce the morphogenesis and 55 settlement of tubeworm larva (5), or impact the correct molting event in filarial nematodes 56 (16). In the squid Euprymna, bacteria control the development of the ciliated appendages of 57 the light organs (17) and in vertebrates they affect the maturation of the gut (18). How 58 microbial signals or environmental cues are received and integrated into the developmental 59 program of the host is only poorly understood. Sensory nerve cells have been shown to 60 recognize several environmental triggers, like temperature in C. elegans $(19,20)$ and 61 nutrients in D. melanogaster (21) and are able to alter phenotypic outcomes during 62 development $(22,23)$. However, it is unclear whether developmental plasticity has common 63 hubs which are triggered by several environmental cues.

64 The freshwater polyp Hydra harbors a stable microbiota within the glycocalyx of the 65 ectodermal epithelium, which is dominated by a main colonizer Curvibacter sp. $(24,25)$. The 66 microbiota is actively maintained by the host (26-28) and is involved in the protection against 67 fungal infection (25). It appears likely that the microbiota has also an influence on the 68 development of Hydra, as constantly occurring developmental processes such as regulation 69 of body size are prone to environmental cues (29). Hydra belongs to the phylum of Cnidaria, 70 the sister group of all bilateria. It has a radial symmetric body plan with only one body axis 71 and two blastodermic layers, the endo- and the ectoderm $(30,31)$. While the stem cells 72 reside in the body column, differentiated cells migrate into the head and foot region (32-35). 
73 The constant proliferation and differentiation of stem cells and the migration of cells from the

74 body column into the extremities necessitates ongoing pattern formation processes. In

75 Hydra, pattern formation is mainly controlled by a Wnt signaling center in the very tip

76 (hypostome region) of the head (36-38). Transplantation of tissue containing the Wnt

77 organizer can induce a secondary axis in recipient polyps depending on the position of

78 excision and transplantation and follows a morphogenetic field model of diffusion reaction

79 (39-42). The formation of the organizer integrates not only position information, but is also

80 dependent on the surrounding temperature (39). In addition, ectopic activation of Wnt-

81 signaling by the inhibition of the GSK3- $\beta$ kinase with Alsterpoullone (ALP) is inducing stem

82 cell differentiation and secondary axis formations (43) by translocating and activating the

83 TCF transcription co-factor $\beta$-catenin into the nucleus (38). The unlimited stem cell capacity

84 and the constant pattern formation in Hydra endows the organism extremely plasticity in

85 terms of regeneration, body size adaption to environment and non-senescence (44-50) On

86 the molecular level temperature acts on the Wnt-TGF- $\beta$ signaling axis influencing the

87 outcome of developmental decisions such as budding and size regulation of the adult polyp

88 (29). All these processes are reversible indicating a high degree of plasticity of the

89 developmental programs in Hydra. How the environmental cues are received and integrated

90 into the developmental program of the animal remains unknown.

91 Here, we describe the taxonomically restricted gene (TRG) eco1 and its paralogue eco2 to

92 be regulated by long-term temperature and microbiota changes in the freshwater polyp

93 Hydra. Changes in the expression of eco genes adjust the developmental decisions during

94 pattern formation by interference with the Wnt-signaling pathway, controlling axis stability

95 and continuous stem cell differentiation in Hydra. 


\section{Results}

97

\section{Temperature and bacteria modulate beta-catenin activity}

99 To consolidate our previous finding that temperature interferes with the Wnt-dependent 100 developmental program in Hydra (29) we treated polyps cultured continuously at $12{ }^{\circ} \mathrm{C}$ and $10118{ }^{\circ} \mathrm{C}$ with Alsterpaullone (ALP) at $18^{\circ} \mathrm{C}$ (Figure 1A). ALP is an inhibitor for GSK3- $\beta$ and

102 causes an activation of the Wnt-signaling pathway leading to the formation of ectopic 103 tentacles in Hydra $(29,43,51)$. The number of ectopic tentacles can be used as a proxy to 104 evaluate Wnt signaling strength in the animal, where higher levels of Wnt signaling leads to a 105 higher number of tentacles. Animals reared at $18^{\circ} \mathrm{C}$ formed $\sim 40 \%$ more ectopic tentacles 106 than animals reared at $12^{\circ} \mathrm{C}$ (Figure 1B), indicating that lower temperatures decreased Wnt107 signaling strength and thus plays a role in controlling axis formation and maintenance of the 108 proliferation zone in Hydra.

A
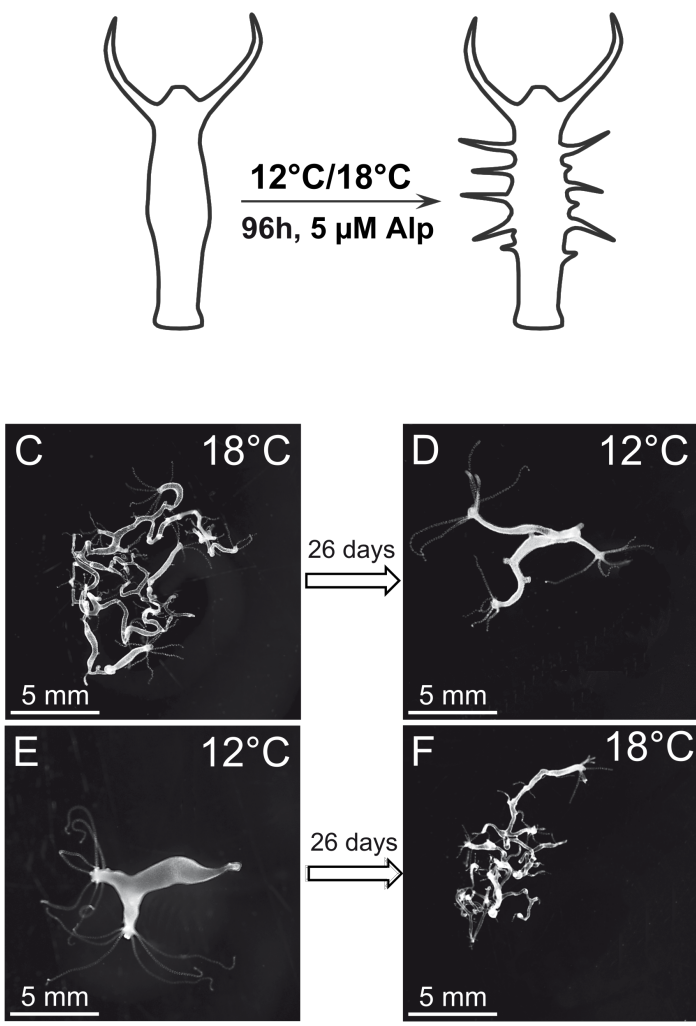
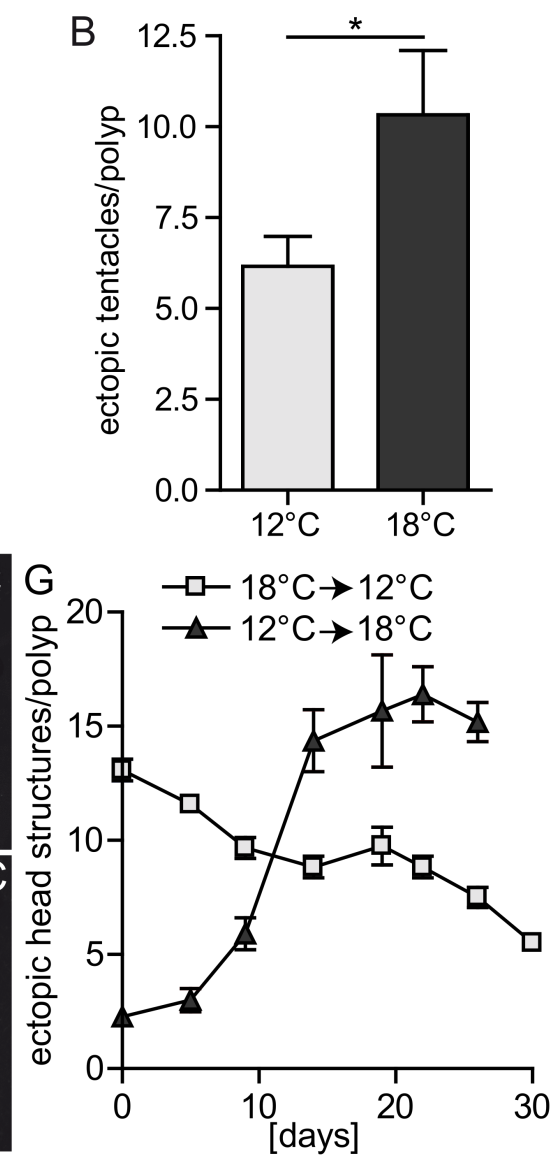

Figure 1: Wnt-signaling is temperature dependent. (A) Animals reared at $12^{\circ} \mathrm{C}$ and $18^{\circ} \mathrm{C}$ were treated with ALP for $24 \mathrm{~h}$, before assessment of ectopic tentacle formation after $96 \mathrm{~h}$. (B) Lower temperature leads to fewer ectopic tentacle formation after ALP treatment. (t-test, $n=12,{ }^{*} p<0.05$ ) (C-F) Constitutive active Wnt signaling in $\beta$-catenin OE animals causes multiple heads/body axes at $18^{\circ} \mathrm{C}$, while the severity of the phenotype was subdued when animals were reared at $12^{\circ} \mathrm{C}$. (G) The number of heads produced by the $\beta$-catenin $\mathrm{OE}$ animals is reversible and depends on the rearing temperature, where surrounding temperatures of $12^{\circ} \mathrm{C}$ resulted in fewer heads per polyp $(n=10)$. 
110 In order to understand how temperature is interfering with the Wnt signaling pathway, we

111 reared transgenic animals, carrying a constitutively active $\beta$-catenin over expression (OE)

112 (38) construct at $12^{\circ} \mathrm{C}$ and $18^{\circ} \mathrm{C}$. Hydra polyps carrying this construct formed multiple

113 secondary axis and pattern formation is significantly disturbed in these animals (Figure 1C-

114 F) (38). Transferring these animals from $18^{\circ} \mathrm{C}$ to $12^{\circ} \mathrm{C}$ rescued this phenotype nearly

115 completely (Figure 1C, D) by reducing the number of heads in these animals over a course

116 of $26 \mathrm{~d}$ (Figure 1G). Interestingly, the effect of temperature on axis formation was reversible,

117 as animals with few axis reared at $12^{\circ} \mathrm{C}$ developed multiple axis within $26 \mathrm{~d}$ if cultured at

$11818^{\circ} \mathrm{C}$ (Figure 1E, F, G). Temperature thereby had neither an effect on the expression of

119 members of the Wnt-signaling pathway nor the $\beta$-catenin OE construct (Supplementary

120 Figure 1).

121 To test whether other environmental factors such as the associated microbiota also affects $\beta$ -

122 catenin dependent development in Hydra, we performed the same ALP-treatment on animals

123 with and without associated bacteria (Figure 2A). Germfree animals responded nearly four

124 times more to the ectopic activation of Wnt signaling compared to control animals (Figure

125 2B-D). In a second experiment we tested, whether recolonization (conventionalizing) of the

126 germfree animals reduced the increased tentacle formation after ALP treatment and found a

127 significant mitigation of the ALP effect in these animals (Supplementary Figure 2,

128 Supplementary Table 1). The observations indicate that not only higher temperatures but 129 also loss of host-associated bacteria increase the Wnt signaling in Hydra and affect 130 maintenance of the proliferation zone along the body column.

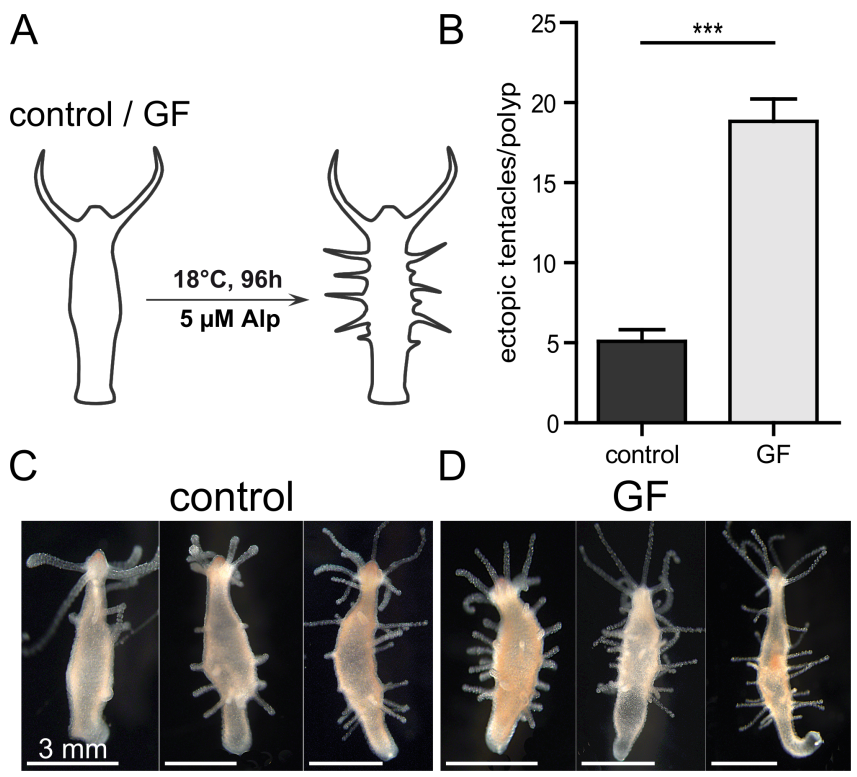

Figure 2: Wnt-signaling is dependent on microbial colonization. (A) Animals were ALP treated for $24 \mathrm{~h}$ and number of generated ectopic tentacles were assessed $96 \mathrm{~h}$ after treatment, comparing the treatment outcome of germfree (GF) and normally colonized animals (control). (b-d) Ectopic tentacle formation is increased when colonizing bacteria were removed, suggesting a role of microbial colonization in pattern formation in Hydra (Mann Whitney $U$ test, $n=58,{ }^{* * *} p<0.0001$ ). 


\section{Both temperature and bacteria influence the expression of eco1 and eco2}

132 To elucidate the underlying molecular mechanism of the environment-development

133 interaction, we compared differentially regulated genes of a previous microarray study

134 comparing GF to control animals (52) with a recent RNA-seq data set (29), which compared

135 the transcriptome of animals reared at $12^{\circ} \mathrm{C}$ and $18^{\circ} \mathrm{C}$. Both sets of differentially regulated

136 genes overlapped in 55 contigs (Figure 3A, Supplementary Table 2). Within this overlap,

13718 genes were regulated in the same direction upon lower rearing temperature and removed

138 bacterial colonization (of these 14 [25,45\%] down, 4 [7.27\%] up). The rest of the genes (37 in

139 total, $67.27 \%$ ) showed contrary regulation in both conditions (19 [34.55\%] down at lower

140 rearing temperature, 18 [32.73\%] up at lower rearing temperature) (Supplementary Table

141 2). As low temperature and removal of bacterial colonizers resulted in contrary responses to

142 ALP we searched for genes with contradicting gene expression in this data set. We ranked

143 the genes according their mean expression, fold change and significance level and excluded

144 metabolic genes for further analysis (see methods for details of candidate gene selection).

145 The contig 18166 was ranked highest in this analysis and showed highest differential gene

146 regulation in the temperature experiment and was on position 15 in the bacterial data set 147 among the 55 contigs. Apart from contig 18166 a paralogue contig (14187) was found to be

148 regulated by both temperature and bacteria (position 5 and 18 in the temperature and

149 bacterial data set, respectively). Both paralogues show high sequence homology, encode for

150 small peptides with a predicted signal for secretion, and contain four conserved cysteine

151 residues (Figure 3B). For both paralogues no homologs were detectable by BLAST search

152 outside the taxon Hydra, indicating that these genes represent taxonomically restricted

153 genes (TRGs) $(53,54)$.

154 We tested the expression of both paralogues upon temperature (Figure 3C) and bacterial 155 cues (Figure 3D) via qRT-PCR and observed a significant up-regulation for both genes at 156 low temperature (Figure 3C) and in the presence of bacterial colonizers (Figure 3D), 157 confirming the initial screening result. Notably, the expression response of both genes to

158 temperature changes was much stronger compared to the bacterial response. The spatial 159 expression pattern of both paralogues were analyzed by whole mount in-situ hybridizations.

160 At $12^{\circ} \mathrm{C}$, both paralogues are expressed in the ectodermal cell layer along the whole body 161 column, while tentacle and foot tissue showed no expression (Figure 3E, F). The expression

162 at $18^{\circ} \mathrm{C}$ is restricted to the foot in the case of 18166 (Figure $3 \mathbf{G}$ ) and to the lower budding 163 region in the case of 14187 (Figure $3 \mathbf{H}$ ) or showed no detectable level of expression at all 164 (89\%) (Supplementary Figure 3). In all cases the expression domain of 18166 at $18^{\circ} \mathrm{C}$ was 165 more expanded than the expression of 14187 (Figure 3G; H, Supplementary Figure 3). 166 These results indicate that the expression of both genes is up-regulated due to the 167 expansion of its expression domain from a foot-restricted expression at $18^{\circ} \mathrm{C}$ to the 168 expression through the whole body column at $12^{\circ} \mathrm{C}$. 
A

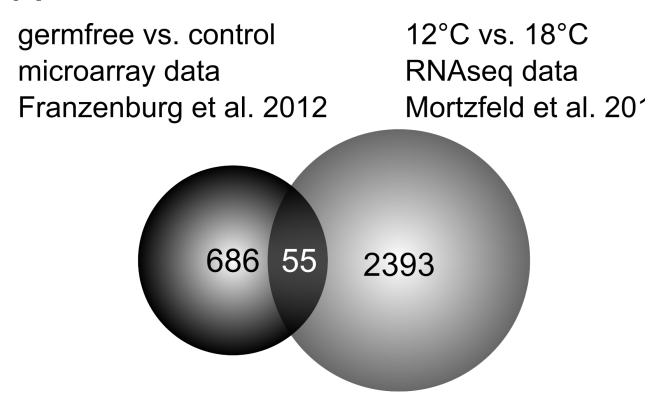

B

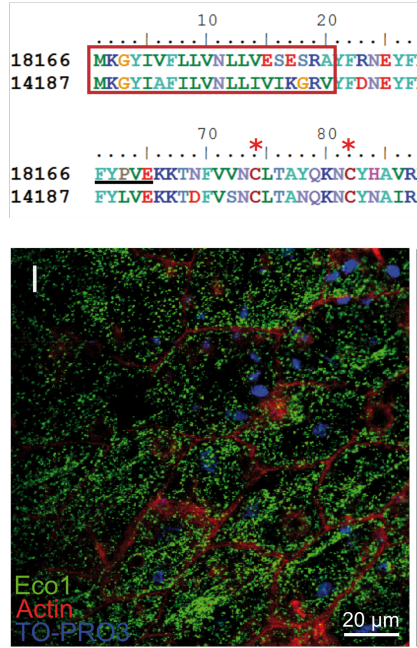

C

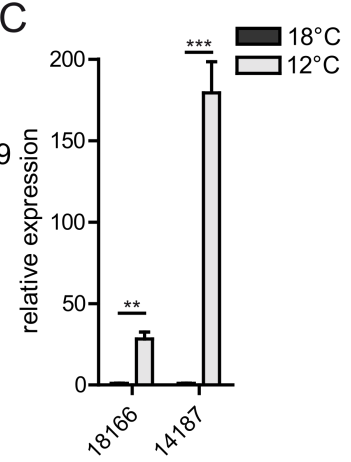

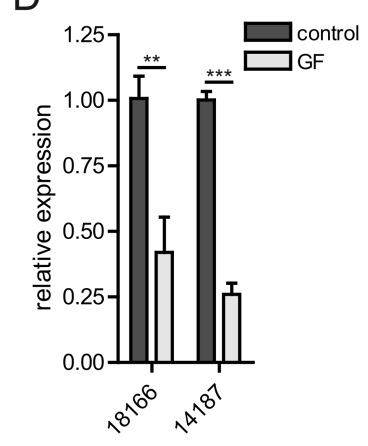

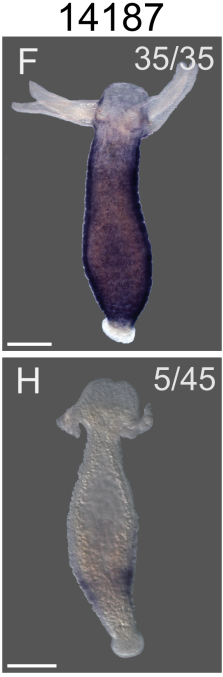

Figure 3: Two TRGs, expressed in the ectoderm, are potential recognition signals for environmental changes. (A) Re-analysis of microarray data, comparing germfree animals with colonized ones, and transcriptomic data, comparing animals at different rearing temperatures, revealed two candidate genes with common regulation upon environmental changes: eco1 and eco2. (B) Sequence analysis of the candidate genes revealed a paralogous relationship between the two genes and a secretion signal peptide (red square), without any domain structure. (C-D) qRT-PCR assessment of eco gene expression in germfree animals and upon temperature shift confirms down regulation of eco1 and eco2 expression at higher rearing temperatures $(n=3$, Two-way ANOVA, Bonferroni post tests, $\left.{ }^{* *} p<0.01,{ }^{* * *} p<0.001\right)$ and in disturbed microbiome conditions $(n=3$, Two-way ANOVA, Bonferroni post tests, $\left.{ }^{*} p<0.05,{ }^{* *} p<0.01,{ }^{* * *} p<0.001\right)$. $(E-H)$ eco genes were expressed in the foot and lower third of the animals at $18{ }^{\circ} \mathrm{C}$ rearing temperature, but the expression domain expands to the body column and parts of the head at $12{ }^{\circ} \mathrm{C}$. (i-j) Immunohistochemistry with a polyclonal antibody raised against a fragment of Eco1 (underlined in b) show the production of the peptides in the ectodermal epithelium and packaging in vesicles localized in the apical part of the cells, which suggests a secretion of the peptide. The images are displayed in pseudocolor, green, red and blue corresponding to Eco1 (AlexaFluor488), the actin cytoskeleton (rhodamine-phalloidin, a proxy for the mesoglea) and the cell nuclei (TO-PRO3).

169 Using a polyclonal antibody, which was generated against a specific peptide encoded by 170 contig 18166 (Figure 3B, underlined sequence), we could observe that the peptide is

171 expressed in the ectodermal epithelial layer and localized in small vesicles (Figure 3I)

172 accumulating at the apical side of the epithelial cells (Figure $\mathbf{3} \mathbf{J}$ ). This cellular localization

173 suggest that the peptide is secreted at the apical side of the ectodermal cells. Considering 
174 their ecological dependence, we termed the genes eco1 (contig 18166) and eco2 (contig

175 14187), respectively.

\section{Expression of eco1 and eco2 response to environmental changes within two weeks}

177 Having confirmed that both genes respond to changes in temperature and bacterial

178 colonization, we assessed the expression of eco1 and eco2 over time in germfree animals

179 and two controls, conventionalized (conv) animals and wildtype polyps (Figure 4A). While 8

180 days post recolonization (dpr) the expression level of eco1 and eco2 in conventionalized

181 animals were still equivalent to the levels in germfree (GF) animals, the expression level of

182 both genes recovered within the second week, with rising expression levels similar to control

183 animals (Figure 4A). Furthermore, we tested if recolonization with the main colonizer

184 Curvibacter sp. alone is sufficient for the regulation of eco genes. Analyzing the expression

185 two weeks after recolonization we observed a recovery of the expression levels of both

186 genes (Figure 4B), indicating that the specific crosstalk between Curvibacter and Hydra is

187 sufficient to regulate gene expression of eco1 and eco2.

188 To get insights into the temporal expression dynamics of eco1 and eco2 after temperature 189 change, we transferred animals cultured at $12^{\circ} \mathrm{C}$ to $18^{\circ} \mathrm{C}$ and vice versa, and monitored the 190 expression over the course of 28 days (Figure 4C). Both genes responded to temperature 191 changes within days, reaching a new stable expression level after around two weeks (Figure

192 4C). Thereby, eco2 showed a higher up regulation at $12^{\circ} \mathrm{C}$ compared to eco1 (Figure 4C),

193 which might reflect the fact that eco2 is expressed at a lower level at $18^{\circ} \mathrm{C}$ compared to eco1

194 (Figure 3 G, H).

195 The fact that both factors, temperature and bacteria, strongly influence the expression of 196 eco1 and eco2 raised the question if both factors are interacting with each other. To 197 disentangle both factors, we generated GF animals and maintained them at $18^{\circ} \mathrm{C}$ or 198 transferred them to $12^{\circ} \mathrm{C}$ (Figure 4D-F). We observed an increase of gene expression in 199 animals transferred to $12^{\circ} \mathrm{C}$ independent of the microbiota state of the animals (Figure 4D200 E), while the absence of bacteria reduced gene expression independent of the temperature 201 (Figure 4F). The effect of temperature was highly significant in an ANOVA ( $p=8.16 E-9)$

202 which was corrected for gene variation while the bacteria effect was only marginal significant, 203 due to the smaller effect size $(p=0.0557)$. The interaction term of temperature and 204 colonization was not significant $(p=0.2)$ indicating no interaction of temperature and 205 colonization in the regulation of eco genes (Supplementary Table 3). These results suggest 206 independent gene regulation by temperature and microbiota for eco1 and eco2. 
A

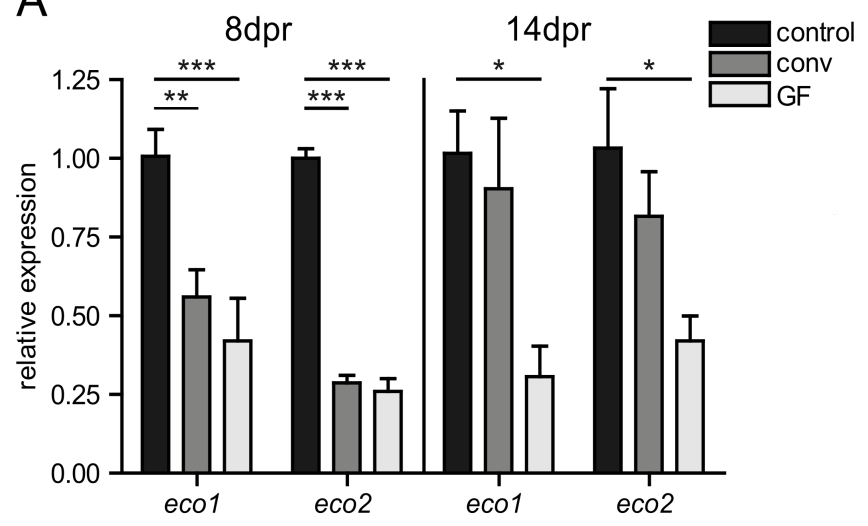

B

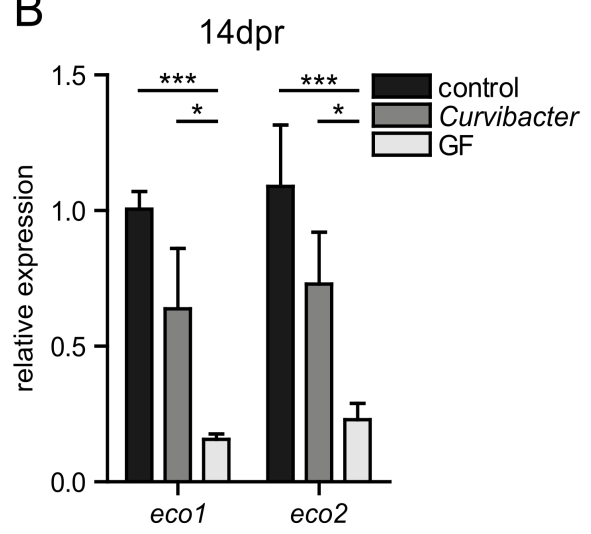

C

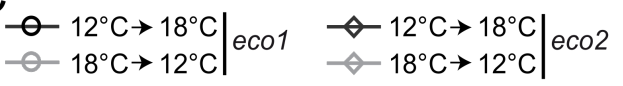

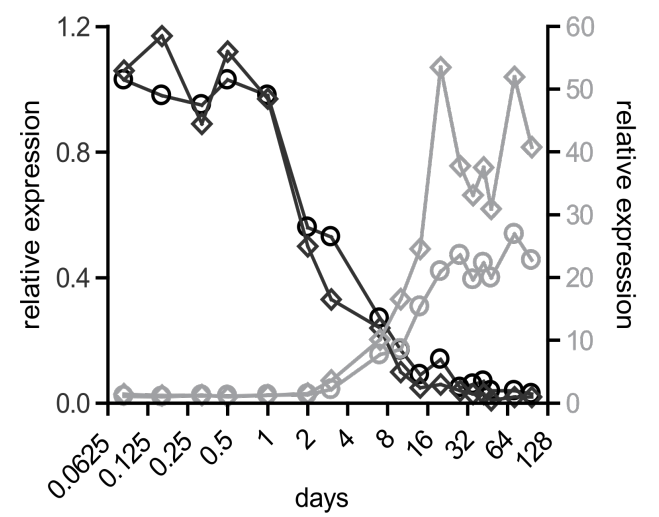

D

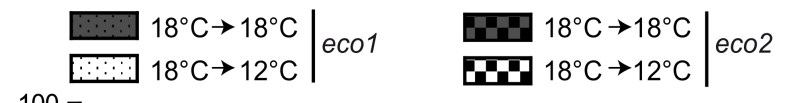

E $\quad 18^{\circ} \mathrm{C} \rightarrow 12^{\circ} \mathrm{C}$
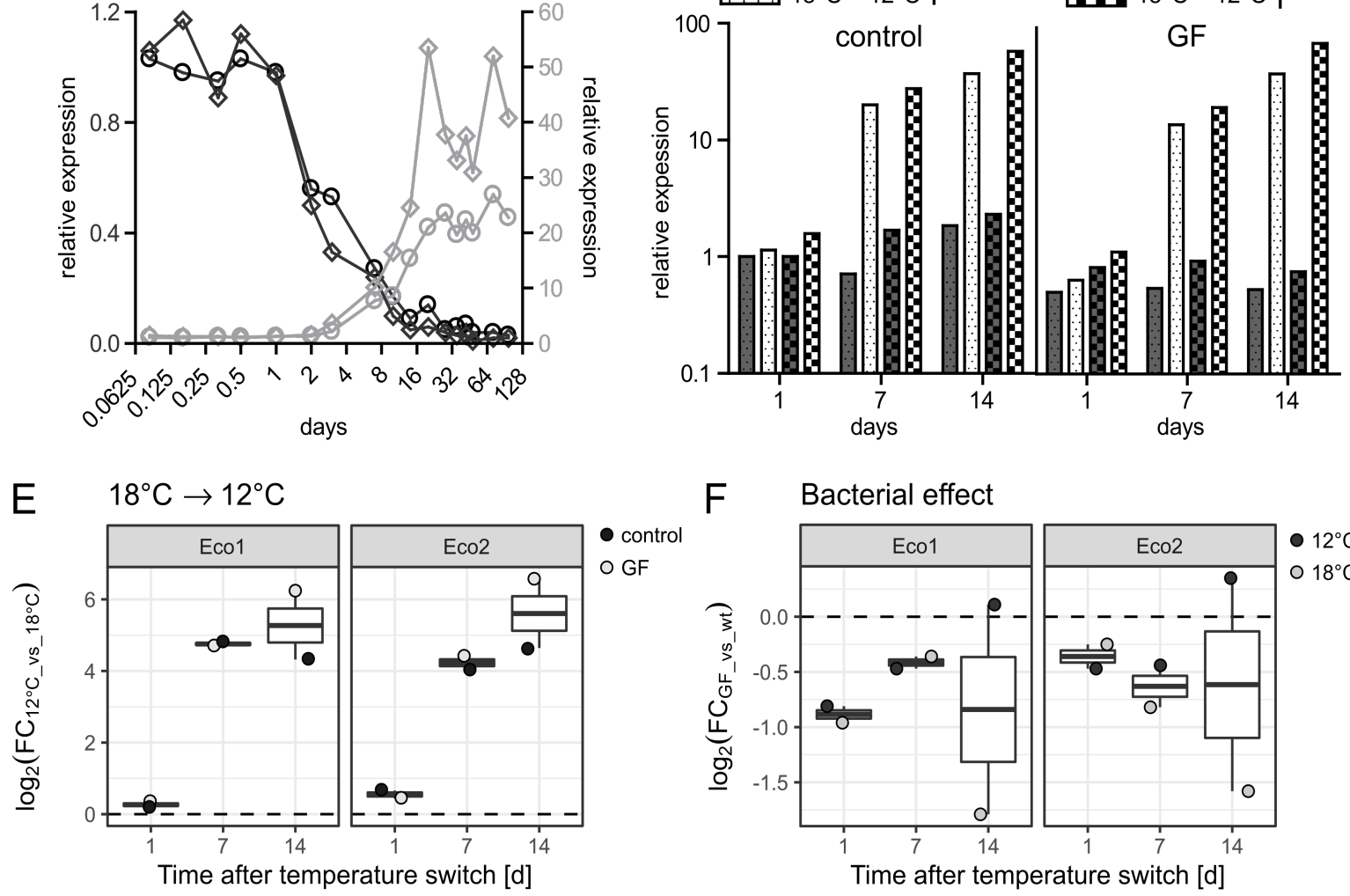

F Bacterial effect

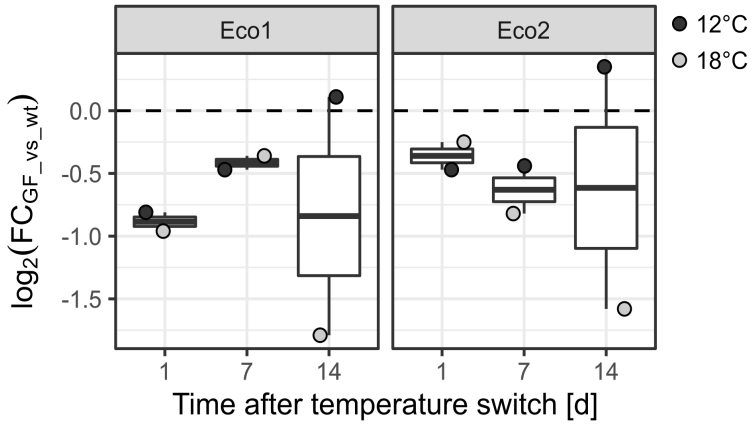

Figure 4: Expression dynamics of eco genes were a long term adaptation to changing microbial state or rearing temperatures. (A) eco gene expression was reestablished by recolonization with bacteria after $14 \mathrm{~d}$, but did not reach normal levels after only $8 \mathrm{~d}$ recolonization ( $\mathrm{n}$ $=3$, Two-way ANOVA, Bonferroni posttests, ${ }^{*} p<0.05,{ }^{* *} p<0.01,{ }^{* * *} p<0.001$ ) (B) Recolonization with the main colonizer Curvibacter sp. alone was sufficient to alleviate the expression suppression of eco genes after $14 \mathrm{~d}$ of colonization. ( $n=4$, Two-way ANOVA, Bonferroni posttests, ${ }^{*} p<0.05,{ }^{* * *} p<0.001$ ) (C) eco gene expression changes were established within 14-16 d upon rearing temperature shifts from $18{ }^{\circ} \mathrm{C}$ to $12{ }^{\circ} \mathrm{C}$ and vice versa. (D) Microbial colonization state and rearing temperature were independent inputs for the expression regulation of eco genes. Gene expression is up regulated upon temperature shifts from $18{ }^{\circ} \mathrm{C}$ to $12{ }^{\circ} \mathrm{C}$, independent of colonization state of the animals. (E, F) The graphic displays effect size cleaned of overlaying variances. (E) The expression of eco genes increases within 14 days after reduction of rearing temperature, independent of the colonization status of the genes (ANOVA, $p=8.16 \mathrm{E}-9$ for temperature, $p=6.99 \mathrm{E}-6$ for temperature-time interaction, see Supplementary Table 3). (F) Removing bacteria from Hydra reduces expression of eco genes independent of temperature (ANOVA, $p=0.0557$ for colonization, $p=0.20$ for colonizationtemperature interaction, see Supplementary Table 3). 
208 In summary, temperature and bacteria dependent regulation of the two genes are reversible

209 and reflect a long-term acclimation to both factors, rather than a short-term regulation and an

210 immediate stress response. The timing of expression changes correlates with the reduction

211 of secondary heads in the $\beta$-catenin $\mathrm{OE}$ animals reared at $12^{\circ} \mathrm{C}$ (Figure 1). Thus, eco1 and

212 eco2 might act as effector genes controlling phenotypic plasticity relaying environmental

213 cues directly to developmental pathways.

214

\section{Eco1 and Eco2 act as antagonists to Wnt-signaling}

216 To functionally analyze the role of Eco1 peptides, we designed a hairpin (HP) construct

217 based on the sequence of eco1 fused to GFP (Figure 5A). We generated two transgenic

218 lines (B5 and B8), which displayed constitutive expression of the HP in the ectodermal

219 epithelial cells. The mosaic nature of genetically modified hatchlings allows for the selection

220 of transgenic and non-transgenic lines, which served as genetically identical control lines

221 (except for the hairpin construct). On the level of in-situ hybridization the transgenic line B8

222 showed a dramatically reduced expression level of eco1 in the whole body column (Figure

223 5B) in comparison to its control line (Figure 5C). Checking the knock-down rate of eco1 by

224 qRT-PCR in both lines revealed a strong down regulation by hairpin-mediated RNAi. Due to

225 high sequence similarity, the hairpin-mediated RNAi targeted also eco2, leading to similar

226 down-regulation compared to eco1 in both transgenic lines (Figure 5D). While at $12^{\circ} \mathrm{C}$ the

227 rate of reduction was between $95 \%-100 \%$ for both genes, the knock-down rate at $18^{\circ} \mathrm{C}$ was

228 between $20 \%-40 \%$ (Figure 5D).

229 To test the hypothesis that Eco peptides act as antagonist to Wnt-signaling we treated both

230 transgenic Eco-knockdown (KD) lines with ALP and compared the number of ectopic

231 tentacles to control animals (Figure 5E). We found a significant 3-fold (B5) and 2-fold (B8)

232 increase in number of ectopically formed tentacles in Eco-KD animals, respectively (Figure

$2335 \mathrm{~F})$. 


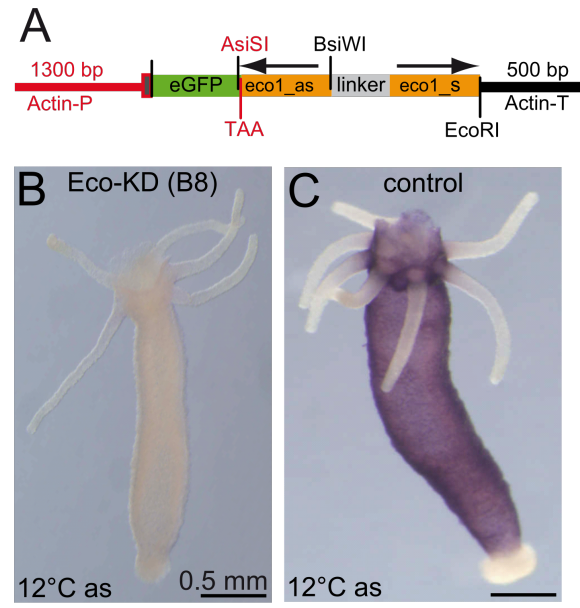

E

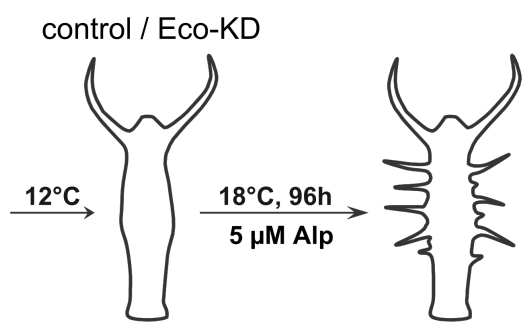

wt

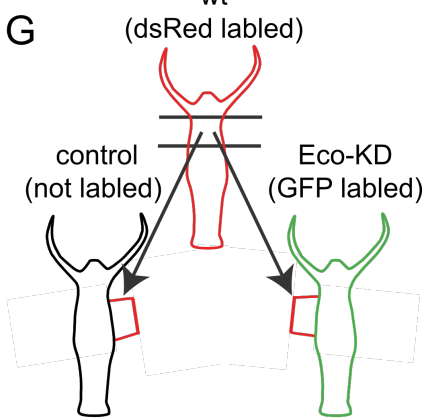

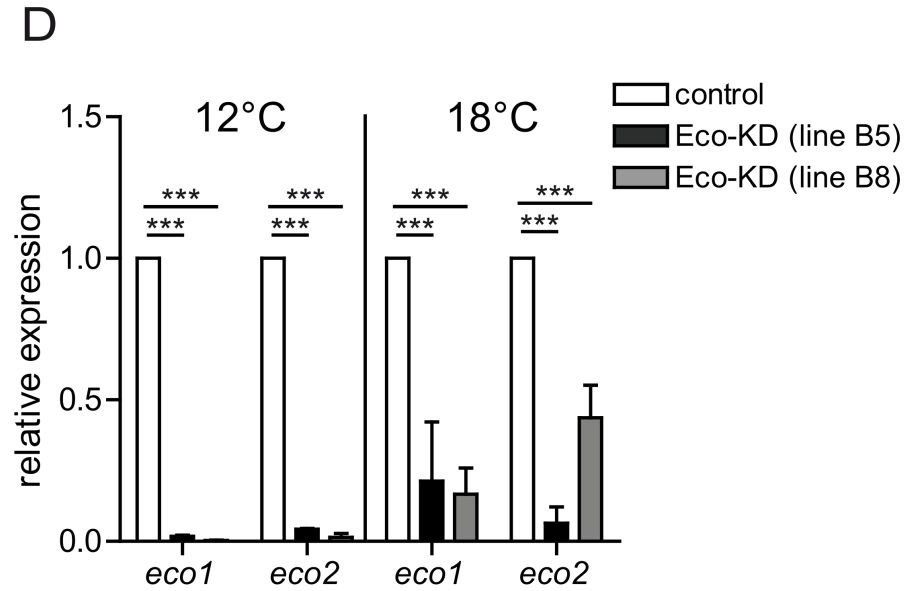

$\mathrm{F}$

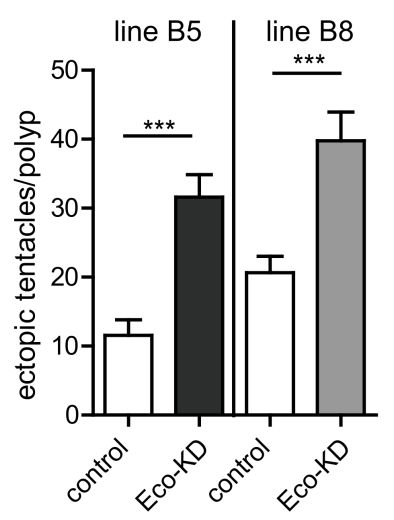

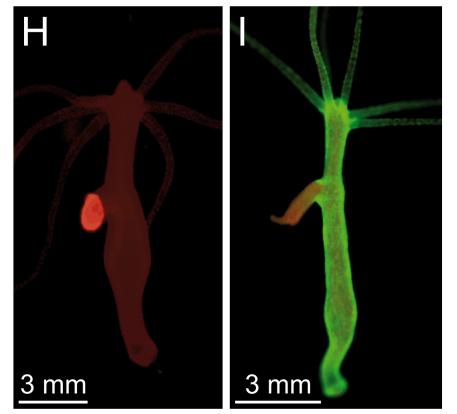

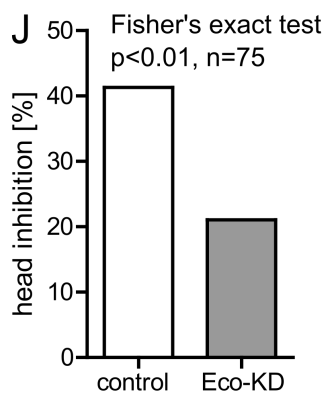

Figure 5: Knockdown of eco genes results in increased Wnt signaling. (a) Eco-hairpin construct for generation of transgenic Hydra (as, antisense; s, sense; TAA, stop codon; P, promoter; T, terminator) (b, c) Whole mount in-situ hybridization of eco1 expression in Eco-KD (b) and control (c) animals. (d) eco1 and eco2 expression in two transgenic lines (B8 and B5) at $12^{\circ} \mathrm{C}$ and $18^{\circ} \mathrm{C}(\mathrm{n}=3$, Two-way ANOVA, Bonferroni posttests, $\left.{ }^{* * *} \mathrm{p}<0.001\right)(\mathrm{e}-\mathrm{f})$ Treating Eco1-KD animals with ALP revealed an increased potential to form ectopic tentacles, indicating a higher Wnt signaling activity. (f) The number of heads formed after transplantation of near head tissue into the body axis of an acceptor polyp serves as a readout for the head inhibition potential, which is governed by the inhibition of the Wnt signaling. (g-h) Control (unlabeled) and Eco-KD (GFP labeled) animals served as acceptor polyps for head tissues from wild type (dsRed labeled) animals to assess the head inhibition potential under disturbed eco expression. (i) Eco-KD polyps showed a reduced head inhibition potential, indicating an impaired Wnt inhibition in these animals. $n=75, p=0.0085$, Fisher's exact test.

234 Since the Wnt signaling is instructive for head regeneration, we tested, whether Eco peptides

235 are involved in the regeneration process. We cut Eco-KD animals reared at $12^{\circ} \mathrm{C}$ and $18^{\circ} \mathrm{C}$ in

236 the middle of the body column, to regenerate a head or a foot (Supplementary Figure 4A).

237 During head regeneration we observed no difference neither in the timing (Supplementary 
238 Figure 4B) nor in the number of tentacles which regenerated between the Eco-KD and

239 control animals (Supplementary Figure 4C). Similarly, foot regeneration was not disturbed

240 in Eco-KD animals (Supplementary Figure 4D). This result indicates no major role of eco

241 genes in the regeneration processes of Hydra.

242 To consolidate the notion of Eco peptides being an antagonist to Wnt-signaling, we

243 performed transplantation experiments to measure the head inhibition potential of Eco-KD

244 animals. In Hydra, head activation and inhibition is governed by a gradient of an activator

245 and inhibitor, following a model first described by Alan Turing and specified by Alfred Gierer

246 and Hans Meinhardt (55-57). The model describes a two component system of molecules,

247 which can explain the head forming properties of Hydra's patterning processes. The idea

248 was experimentally tested by Harry MacWilliams in the 1970s and 80s, using transplantation

249 techniques $(58,59)$. In his experiments he described properties of the head inhibitor and

250 head activator in the animals, using the fact, that head near pieces have organizer

251 functionality (40) and can induce a head in the body column of an acceptor polyp. He

252 described two main findings: first, the rate of head induction increased as the site of

253 transplantation was further away from the head of the donor (head inhibition gradient)(59).

254 Second, the potential to form a head decreases with the distance to the head of the excised

255 pieces (head activation gradient) (58). We used a similar approach and assessed properties

256 of the head inhibition gradient in the Eco-KD background, by comparing the fraction of heads

257 formed in Eco-KD and control animals. To this end, we transplanted head near pieces

258 (directly beneath the tentacle ring) from control donor animals into the body column

259 (approximately one-third from the head) of acceptor animals. We chose the site of

260 transplantation (one-third length from the head) as it was reported that head formation was

261 medium to low in this experimental setting (60). If our notion of decreased head inhibition for

262 the knockdown of the eco gene expression was true, we expected an increased fraction of

263 heads formed after transplantation of head near tissue into the body column of Eco-KD

264 animals.

265 We found, that the fraction forming heads after transplantation is doubled in Eco-KD animals

266 (31 of 75), compared to control animals (16 of 76), indicating a reduced head inhibition

267 potential (Figure 5G-I). Together with the ALP experiment, these results demonstrated that

268 Eco peptides antagonize the effects of Wnt-signaling. Lastly, we checked whether eco gene

269 expression is regulated by the Wnt pathway and can act as a feedback mechanism in the

270 head formation process. We treated animals with different concentrations of $\operatorname{ALP}(0.2,1$, and

$2715 \mu \mathrm{M})$ for $24 \mathrm{~h}$ and measured eco expression via qRT-PCR, but could not detect a regulation

272 of the genes (Supplementary Figure 5).

273 Taken together these results show that the eco genes are able to relay environmental

274 signals, like bacterial colonization and temperature, to the Wnt-signaling cascade and by that

275 modulate axis and head formation in Hydra according to environmental conditions. 


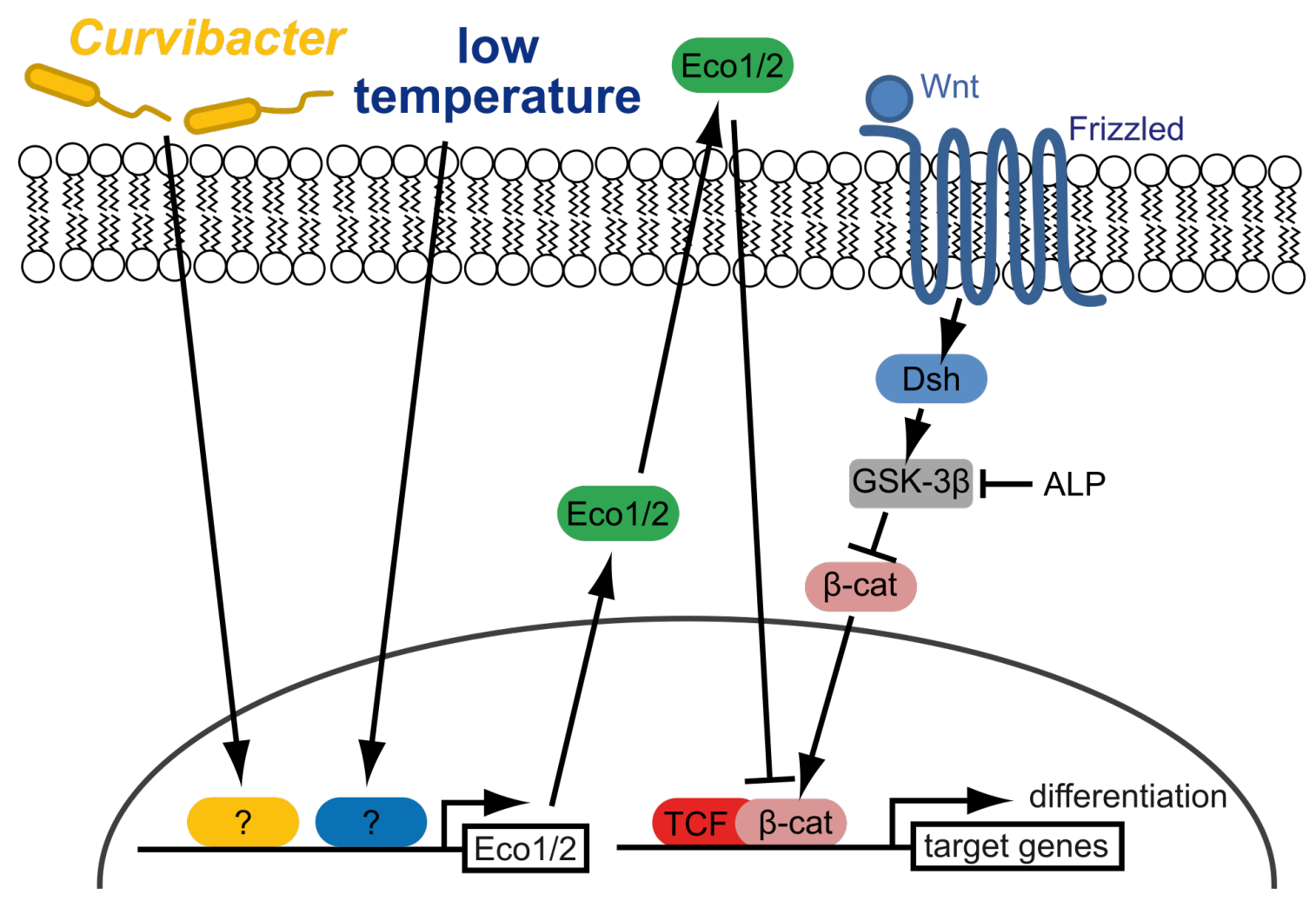

Figure 6: Eco peptides are environmentally triggered inhibitors of Wnt signaling. Microbial colonization and low temperature are independent inputs for Eco peptides and are able to induce its transcription. Eco peptides are synthesized as small peptides, packed into vesicles and secreted into extracellular matrix of the ectoderm. By an unknown mechanism Eco peptides are recognized and the Wnt signaling is inhibited. The inhibition takes place downstream of the $\beta$-catenin stabilization, presumably at the expression of Wnt target genes as Eco expression were able to inhibit activation of the pathway at the GSK-3 $\beta$ level after ALP treatment (see text).

\section{Discussion}

Wnt-signaling: an evolutionary conserved signaling hub integrating environmental signals to stem cell behavior

281 The Wnt-signaling pathway most likely evolved in the common ancestor of multicellular 282 animals. Members of the pathway are present in all metazoan animals, but not in fungi, 283 plants, or unicellular eukaryotes, and have regulatory functions in embryogenesis and cell 284 differentiation (61).

285 In Hydra the Wnt pathway is involved in head formation (36), control of bud formation (37, 286 62) and the differentiation of stem cells $(63,64)$. Most Wnt family member are expressed in 287 the tip of the hypostome of Hydra (37) and the Wnt pathway has been shown to form the 288 activating agent in the head organizer of Hydra $(36,37)$. Wnt corresponds to the head inducer in the Gierer-Meinhardt model, which describes a self-organizing system of head activation (HA) and head inhibition $(\mathrm{HI})$ and is suitable to explain regeneration and axis 
291 formation in Hydra (42). In this model the HI would correspond to a molecule/gene which is

292 activated by Wnt and is inhibiting the Wnt pathway. Thus, the expression of such a gene

293 would be expected to be expressed in a graded manner from head to foot. Here, we show

294 that Eco peptides antagonizes the Wnt-signaling pathway (Figure 6) by reducing both

295 ectopic tentacle formation after ALP treatment (Figure 5F) and by transplantation

296 experiments (Figure 5H-J). However, the expression domain of eco genes is restricted to the

297 foot at $18^{\circ} \mathrm{C}$ and expands to the head region only, if the animals were reared at $12^{\circ} \mathrm{C}$ for at

298 least 14 days (Figure 3E-H, Figure 4C). The expansion of the expression domain of eco

299 genes corresponds to a dramatic increase of the gene expression level, which seems not to

300 appear graded in any form (Figure 3C, E-H). Eco peptides do thus not equal the proposed

$301 \mathrm{HI}$ of the Gierer-Meinhardt model and therefore add another layer to the Wnt-pathway

302 regulation in Hydra.

303 The properties of the $\mathrm{HI}$ in Hydra were elaborately determined by transplantation

304 experiments by MacWilliams (39). Inhibitor level changes occurred during regeneration within

305 6-24 $\mathrm{h}$ after ablation, indicating that the here described inhibitor of the Wnt signaling acts on

306 completely different time scales, than the immediately responding $\mathrm{HI}$. MacWilliams further

307 noted that temperature changes had an influence on the $\mathrm{HI}$ potential of Hydra. However,

308 these temperature changes were also applied only several hours before transplantation,

309 where eco expression changes have not occurred (Figure 4C). We therefore argue, that Eco

310 peptides do not contribute to the immediate organizing function of Wnt during head

311 formation, but is rather adjusting background levels of Wnt signals throughout the body. This

312 notion is confirmed by the undisturbed regeneration of Eco-KD animals (Supplementary

313 Figure 4) and the otherwise normal appearance of the polyps (including regular budding). A

314 regulation of the background Wnt signaling strength by Eco peptides seems reasonable

315 because Wnt signaling is important for size regulation in Hydra by means of bud initiation

$316(29,62)$ and body size is regulated with temperature $(29,49)$. In addition, the variation of

317 multiple axes in the $\beta$-catenin OE animals at different rearing temperatures occurred in the

318 same time frame as eco gene regulation upon temperature shift (Figure 1C-G). Altogether,

319 this could imply a function of Eco peptides in adjustment of Wnt signaling strength as they

320 are regulated with temperature and antagonize Wnt signaling. However, Eco-KD animals

321 showed now obvious size differences in our cultures, which indicates, that the temperature-

322 Wnt regulation seems to be more complex and can not be reduced to Eco signaling alone.

323 Notably, the proposed $\mathrm{HI}$ of the Gierer-Meinhardt model remains enigmatic on the molecular

324 level till today, though various candidates have been proposed, for instance a Hydra dickkopf

325 homolog $(65,66)$, the transcription factor Sp5 (67), or the glycoprotein thrombospondin (68),

326 but none of them seem to resemble all assumed properties of the $\mathrm{HI}$ in the Gierer-Meinhardt

327 model. Further, several downstream genes of the Wnt signaling pathway have been shown

328 to be involved in specific aspects of Wnt signaling, for example the homeobox gene rax is 
329 important for tentacle formation (69), PKC signaling seems to be important for head 330 regneration (70), but not in bud formation (71), while ERK signaling was essential for both 331 processes $(70,71)$. We thus argue, that several levels of Wnt-inhibition exist and that the 332 activity of Eco peptides provides one mechanism. Until now, it is unclear how Eco peptides 333 antagonizes Wnt pathway, but we assume that they act downstream of $\beta$-catenin given the 334 following arguments. First, we showed that Eco-KD animals have a higher probability of 335 forming tentacles after ALP treatment, but have normal regeneration capability, thus Rax 336 could be a target transcription factor inhibited upon Eco signaling (69). Secondly, we showed 337 that low temperature is antagonizing the effect of over expressed $\beta$-catenin. As $\beta$-catenin 338 was mutated in a way that it was stabilized against APC dependent degradation (38), we 339 argue that the antagonistic activity is most likely downstream of $\beta$-catenin and independent of 340 the APC pathway. Therefore, we predict the presence of an endogenous receptor that binds 341 Eco peptides and activates a signaling cascade antagonizing $\beta$-catenin activity.

342 To date the inputs of eco gene regulation on the molecular level are unknown. We can 343 exclude, that Wnt signaling actively regulates eco genes, which would be expected if Eco 344 signaling is involved in the immediate head formation process. However, one could speculate 345 on acyl-homoserine-lacton ( $\mathrm{AHL}$ ) as a possible recognition molecule. We previously showed 346 that AHLs produced by Curvibacter are quenched by the Hydra host to avoid detrimental 347 gene expression of Curvibacter on the host (24). This direct interaction indicates an active 348 recognition of AHLs by the host and would mediate a possible route of regulating eco gene 349 expression. From the microarray data we can exclude also a MyD88 mediated eco 350 regulation, as MyD88-KD animals showed no differences in expression level of eco genes 351 (52).

352 Predicting inputs for the temperature signal is unequally more difficult, as to date no definite

353 temperature sensing mechanism has been found in Hydra. TRPs are known to sense high 354 and low temperature and have been identified in Hydra (72). TRPM3 has also been linked to 355 high temperature sensation (heat shock) in Hydra (73) but if similar mechanisms exist for 356 cold temperature or whether they can mediate the long term effect of eco gene expression is 357 unclear to date. Eco expression might be regulated by other head inhibiting substances as 358 MacWilliams has suggested, that physical properties of the $\mathrm{HI}$ change at different 359 temperatures, resulting in a longer range of action at lower temperatures, which eventually 360 might translate in an activated eco gene expression (39).

361 Increased Wnt-signaling causes the stem cells in Hydra to differentiate and to lose their 362 potential to self-renew $(63,64)$. Interestingly, the expression of both Eco peptides is 363 regulated by the presence of Curvibacter, the main bacterial colonizer of Hydra, and low 364 temperature. Individual pathways may signal both external signals to the promotor of eco 
365 genes, as both factors regulate the expression of both genes independently (Figure 6, 366 Figure 4D).

367 Our model suggests, that the ratio of recognized Wnt and Eco peptides by an individual cell 368 determines the activation of Wnt-target genes. Thereby, the opposing signaling outcomes of 369 Wnt and Eco would determine the degree of differentiation in the tissue, as increased Wnt 370 signaling causes the differentiation of stem cells $(63,64)$. This process is mediated by Myc1 371 in interstitial cells, which is directly affected by the increase of Wnt signals due to ALP 372 treatment (64). Given, that Eco peptides are able to counteract increased Wnt signals, we 373 thus argue that the eco genes integrate environmental signals into the developmental 374 program and thereby promote the stemness of the cells in the body column of Hydra.

376 There are several studies in vertebrates that showed the integration of environmental signals 377 into the Wnt pathway. In zebrafish, the intestinal bacterium Aeromonas veronii enhances $\beta$ 378 catenin stability after recognition by MyD88 resulting in higher cell proliferation in the 379 intestine (74). In human epithelial cells the CagA peptide produced by Helicobacter pylori, 380 activates $\beta$-catenin, leading to transcriptional upregulation of genes implicated in cancer $(75$, 381 76). In addition, activation of the aryl hydrocarbon receptor by natural ligands, which are 382 converted from dietary tryptophan and glycosinolates by intestinal microbes $(77,78)$, results 383 in the degradation of $\beta$-catenin (78) and the suppression of intestinal carcinogenesis. We 384 showed another mechanism, how bacterial signals are integrated into the Wnt signaling 385 pathway, via an orphan peptide not present outside the Hydra genus. All described 386 mechanisms are highly specific to each of the different model systems (MyD88, CagA, AhR, 387 Eco1) and thus most likely evolved independently, which highlights the necessity of individual adaptation dependent on the life styles to cope with changing environments. However, conserved developmental signaling like the Wnt pathway seems to form signaling hubs to integrate environmental cues. The Wnt signaling pathway thereby fulfills central tasks in pattern formation as well as stem cell regulation in all metazoans and is clearly an important target to mediate developmental decisions upon environmental changes.

\section{Orphan genes as circuit of environmental cues to host development}

395 This study adds another example to taxonomic restricted or orphan genes as important factors for adaptations and stresses the importance of these fast evolving genes for the interaction with the environment. Orphan genes have been found to play important roles by recruiting new energy resources $(79,80)$, and occupying new habitats (81). Orphan genes often display functions in developmental programs $(81,82)$, immunity $(26,83)$ and mediate

400 interaction with the environment $(54,84,85)$. Here we support this notion by showing that the 401 two eco paralogues interact with the environment in a way that the current conditions for 
402 temperature and microbiota association are sensed and signaled to the Wnt pathway.

403 Thereby, the developmental program is tuned by environmental factors via the regulation of

404 the two orphan peptides Eco1 and Eco2.

405

406 Environment matters

407 Animal development has traditionally been viewed as an autonomous process directed by 408 the host genome. In recent years, it got evident that biotic and abiotic cues provide a variety 409 of signals that are integrated into the developmental program. These observations resulted in 410 the Eco-Evo-Devo concept $(7,8)$. Our results provide new evidences for this concept on 411 different levels. Firstly, our study supports the idea that development is plastic and 412 responsive to abiotic (temperature) and biotic (microbiota) factors, as eco gene expression is 413 highly dependent on these factors. Secondly, we show that evolution of new traits does not 414 necessarily demand the change in core developmental pathways, but that newly obtained 415 genes can act as modulators of these pathways mediating a gain of function in 416 developmental programs. Thirdly, we show that evolutionary young genes, which modulate 417 conserved developmental signaling cascades, can mediate phenotypic plasticity and 418 increase robustness of patterning formation after disturbance. 
422 Animal culture. All experiments were carried out with either wild type or transgenic Hydra

423 vulgaris AEP (Hydra carnea $(86,87)$ ) which were cultured in Hydra medium (HM, $0.28 \mathrm{mM}$

$424 \mathrm{CaCl}_{2}, 0.33 \mathrm{mM} \mathrm{MgSO}_{4}, 0.5 \mathrm{mM} \mathrm{NaHCO}_{3}$ and $0.08 \mathrm{mM} \mathrm{KCO}_{3}$ ) at $18{ }^{\circ} \mathrm{C}$ with a $12 / 12 \mathrm{~h}$ light-

425 dark cycle. Animals were fed ad libitum 2-3 times the week.

427 Transgenic animals. The $\beta$-catenin over expression construct contained a truncated $\beta$ 428 catenin (AA $\Delta 1-138$, containing the phosphorylation site important for Wnt signaling 429 transduction) obtained from Hydra magnipapillata terminally fused to eGFP in a modified 430 Hot-G Bluescript II SK + backbone (alias: pHyVec4, Steele, Genebank: DQ385853) (38). The 431 Eco1 hairpin constructs were cloned into a pGEM-T backbone obtained from Hydra vulgaris 432 AEP (Hydra carnea) sequences (Compagen: HAEP_celera_v1_contig18166) containing 433 base pair 3-303 with a 307 bp linker. dsRED and eGFP labelling constructs were codon 434 usage optimized for Hydra and cloned into pGEM-T expression vectors. All constructs were 435 driven by constitutively expressed Hydra magnipapillata actin promoters $(\sim 1.5 \mathrm{~kb}$ upstream 436 the actin gene) and terminated by an actin terminator ( $1 \mathrm{~kb}$ downstream of the gene). 437 Stable transgenic animals were generated by microinjection of genetic constructs into 2-8 438 cell blastomere of Hydra. Transgenic animals hatched with a mosaic expression of eGFP, 439 which served for selection of transgenic cells. The asexual mode of reproduction was used to 440 select for transgenic cells and generate full transgenic animals on the on hand, while on the 441 other hand non transgenic cells were selected to generate a non-transgenic line, which 442 served as a control, containing the same genetic background.

444 Antibiotics treatment and recolonization. To render animals germ-free, we treated Hydra 445 with a cocktail of ampicillin, rifampicin, streptomycin, and neomycin ( $50 \mu \mathrm{g} / \mathrm{ml}$ each) in sterile $446 \mathrm{HM}$ for two weeks and daily exchange of the medium. To control for germ-freeness a 447 randomly chosen polyp from each batch were homogenized and plated on R2A-Agar, 448 missing CFU indicated removal of bacteria. Furthermore, whole DNA from a randomly 449 chosen polyp of each batch were isolated (DNeasy Blood \& Tissue Kit, Quiagen) and a PCR 450 for bacterial DNA contamination was performed (Eub-27F: AGAGTTTGATCCTGGCTCAG, 451 Eub-1492R: GGTTACCTTGTTACGACTT).

452 To control for the effect of antibiotics in our experiments, animals were conventionalized by 453 recolonizing them with naturally hosted bacteria after antibiotic treatment. To this end, for 454 each germ-free Hydra one untreated animal were homognized, resuspended in $100 \mu \mathrm{l}$ 455 autoclaved $\mathrm{HM}$ and added to $\sim 4 \mathrm{ml} \mathrm{HM}$ containing the germ-free animals. The animals were 456 washed $24 \mathrm{~h}$ after recolonization with sterile HM to remove excess bacterial load. 
458 Alsterpaullone experiment. Animals were fed one day prior experiment and treated with $4595 \mu \mathrm{M}$ Alterpaullone (ALP, Sigma-Aldrich) for $24 \mathrm{~h}$ to inhibit the glycogen synthase kinase $3 \beta$ 460 (GSK3- $\beta$ ) and activate the Wnt signaling pathway at $18^{\circ} \mathrm{C}$, regardless of previous rearing 461 conditions. After treatment, the polyps were washed and incubated in HM before assessment 462 of ectopic tentacle formation under the binocular $4 \mathrm{~d}$ after treatment. To regard any form of 463 the temperature reaction norm we assessed the number of tentacles per polyp after tentacles 464 were clearly developed so that a further increase in number of tentacles could not be 465 observed, even at later time points.

467 Temperature treatment of $\beta$-catenin animals. $\beta$-catenin over expression animals were 468 reared at either $18^{\circ} \mathrm{C}$ or $12^{\circ} \mathrm{C}$ and standard conditions prior experiment. Animals were 469 transferred to treatment temperature $\mathrm{HM}\left(18{ }^{\circ} \mathrm{C} \rightarrow 12^{\circ} \mathrm{C} ; 12^{\circ} \mathrm{C} \rightarrow 18^{\circ} \mathrm{C}\right)$ kept as single 470 polyps in a 12-well plate. Head structures of the visually largest animal were assessed at day $4710,5,9,14,19,22,26$, and 30 . Smaller animal fragments, which might have appeared during 472 the experiment, were removed from the cavity.

474 RNA extraction, cDNA generation, qRT-PCR. Total RNA was isolated by dissolving 15-25 475 animals in $1 \mathrm{ml}$ TRIzol (Invitrogen) by vortexing, after starvation for 2 days. After addition of $476300 \mu \mathrm{L}$ chloroform (p. a.), samples were centrifuged $\left(12,000 \mathrm{~g}\right.$ at $4^{\circ} \mathrm{C}$ ), the resulting aqueous 477 phase was transferred in a clean tube, and $400 \mu \mathrm{l}$ ethanol (99.9\%) was added. The solution 478 was cleaned and desalted using the silica column protocol from Ambion PureLink RNA Mini 479 Kit (Thermo Scientific), including an on column DNAse digestion step. 650 ng RNA was used 480 to generate cDNA applying the protocol of the First Strand cDNA Synthesis Kit (Fermentas). 481 Resulting cDNA was equilibrated within each experimental setup by semi-quantitative PCR 482 using primer for the house keeping gene ELF1a. Equal amounts (according to PCR 483 quantification) were used with the GoTaq qPCR Master Mix (Promega) in a 7300 real-time 484 PCR system $(A B I)$. For data analysis the simplified method after Pfaffl (88) was used, 485 assuming a primer efficiency of $100 \%$.

487 Gene selection from transcriptomic analysis. We defined a gene set from the overlap of 488 differentially expressed genes from a microarray comparing GF vs. recolonized animals and 489 in a RNA-seq experiment comparing $12^{\circ} \mathrm{C}$ vs. $18^{\circ} \mathrm{C}$ rearing temperature (55 genes in total) 490 (29, 52). For technical details of RNA-seq and microarray analysis, see $(29,52)$. This gene 491 set was associated with ranks according mean expression, $p$-value and fold change for both 492 conditions (decreasing order for fold change and mean expression, increasing order for $p$ 493 values). The ranks for each category were summed, to generate a score which was used to 494 sort the genes. The genes Eco1 (contig 18166) and Eco2 (contig 14187) were at position 2 495 and 7 in this list. We did not consider the first gene in the table (a serine acetyltransferase, 
contig 18585) as it was predicted to be associated with metabolic changes which was not the

497 focus of this study. Eco2 was considered only after further investigation of Eco1 and

498 appearing also in a high rank in this list.

500 In-situ hybridization. Whole open reading frame of eco1 and eco2 where cloned into 501 pGEM-T (Promega). DIG-labeled probes where generated using T7/SP6 transcriptions start 502 sites and the digoxigenin RNA Labeling Mix kit (Roche) after manufactures instructions. 503 Hybridization was performed as described previously (89), in short: animals were relaxed 504 with $2 \%$ urethan for 2 min at $4{ }^{\circ} \mathrm{C}$, fixed in $4 \%$ PFA over night at $4{ }^{\circ} \mathrm{C}$, washed three times á 50510 min with PBT (PBS + $0.1 \%$ Tween), and bleached in methanol (100\%) three times for 506 minimum $30 \mathrm{~min}$. Methanol was washed out with four decreasing concentrations of ethanol in 507 PBT (100\%, $75 \%, 50 \%, 25 \%$ v/v) followed by three times PBT washing steps, all 10 min or 508 longer on a shaker. Samples were digested with $10 \mathrm{mg} \mathrm{ml}^{-1}$ Proteinase $\mathrm{K}$ in PBT for $20 \mathrm{~min}$ 509 at room temperature and digestion was stopped by two subsequent washing steps with $5104 \mathrm{mg} \mathrm{ml}^{-1}$ glycine in PBT, followed by three PBT washing steps each 10 min on a shaker. In 511 order to acetylate positve charges in the samples and reduce background we treated 512 samples twice with triethanolamine $(0.1 \mathrm{M}, \mathrm{pH} 7.8) 5 \mathrm{~min}$, once more with triethanolamine 513 adding $2.5 \mu \mu^{-1}$ acetic anhydrid for $5 \mathrm{~min}$ to add another $2.5 \mu \mathrm{ml}^{-1}$ acetic anhydrid for 514 another $5 \mathrm{~min}$. The samples where washed three times in PBT, refixed in 4 \% PFA over night 515 at $4{ }^{\circ} \mathrm{C}$ and washed another three times in PBT to remove fixative. Samples were treated 516 twice with $2 x \operatorname{SCC}(0.3 \mathrm{M} \mathrm{NaCl}, 30 \mathrm{mM}$ tri-sodium citrate, $\mathrm{pH} 7)$ for $10 \mathrm{~min}$ at room 517 temperature and twice for $20 \mathrm{~min}$ at $70{ }^{\circ} \mathrm{C}$, to inactivate endogenous phosphatases. To 518 transfer the samples into hybridization solution (5x SSC $+50 \%$ formamide $(\mathrm{v} / \mathrm{v}), 0.02 \%$ 519 Ficoll (w/v), $0.02 \%$ bovine serum albumin (w/v), $0.02 \%$ polyvinylpyrolidone (w/v), $0.1 \%$ 520 Tween20 (v/v), $0.1 \%$ CHAPS (w/v), $100 \mathrm{\mu g} \mathrm{ml}^{-1}$ Heparin), the medium was exchanged to 521 prewarmed $50 \%$ hybridization solution in $2 x$ SSC for $10 \mathrm{~min}$ at $57^{\circ} \mathrm{C}$, followed by $10 \mathrm{~min}$ in 522 hybridization solution at $57^{\circ} \mathrm{C}$ and $2 \mathrm{~h}$ blocking in hybridization solution $+100 \mu \mathrm{g} \mathrm{ml}^{-1} \mathrm{tRNA}$ 523 at $57^{\circ} \mathrm{C}$. Around $20 \mathrm{ng} \mathrm{ul}^{-1}$ in-situ probes were denatured for $10 \mathrm{~min}$ at $70{ }^{\circ} \mathrm{C}$ in $10 \mathrm{x} \mathrm{SSC}+$ $52450 \%$ formamid. The denatured probe was added to the hybridization solution + tRNA to a 525 final concentration of $2 \mathrm{ng} \mathrm{\mu l}^{-1}$ and incubated over night at $57^{\circ} \mathrm{C}$. Sense probes were used 526 equally and served as negative control. To remove the probes and prepare antibody staining, 527 the samples were washed in four steps of decreasing hybridization solution in $2 x$ SSC $528(100 \%, 75 \%, 50 \%, 25 \%)$ for $10 \mathrm{~min}$ at $57{ }^{\circ} \mathrm{C}$ each. Afterwards, samples were washed 529 twice in $2 \times$ SSC containing $0.1 \%$ CHAPS for $30 \mathrm{~min}$ at $57^{\circ} \mathrm{C}$ and twice in MAB-T (100 mM 530 maleic acid, $150 \mathrm{mM} \mathrm{NaCl}, 0.1 \%$ Tween20 (v/v), pH 7.5) for $10 \mathrm{~min}$ at room temperature. To 531 block unspecific antibody binding sites, the samples were blocked with MAB-T $+0.1 \%$ 532 bovine serum albumin for $1 \mathrm{~h}$ at room temperature and with MAB-T $+0.1 \%$ bovine serum 533 albumin, $20 \%$ heat inactivated sheep serum for $2 \mathrm{~h}$ at $4{ }^{\circ} \mathrm{C}$. Anti-digoxigenin alkaline 
534 phosphate linked fab fragments (Roche) were used to detect probes by incubating the 535 samples with a 1:2000 solution in MAB-T $+0.1 \%$ bovine serum albumin, $20 \%$ heat 536 inactivated sheep serum over night at $4{ }^{\circ} \mathrm{C}$. Excess antibody solution was removed by 8 537 washes with MAB-T for $15 \mathrm{~min}$ at room temperature. Sample staining was prepared by one 538 NTMT (100 mM NaCl, 100 mM TRIS-HCl, 50 mM MgCl2, $0.1 \%$ Tween20 (v/v), pH 9.5) wash 539 and incubation with NTMT $+1 \mathrm{mM}$ Levamisol for $5 \mathrm{~min}$ to inhibit unspecific endogenous 540 alkaline phosphatases. Staining was performed by incubation of the samples in NTMT $+2 \%$ 541 NBT/BCIP in dark until a clear staining was obtained. The reaction was stopped with three 542 washes of aqua dest. before dehydration in with three steps increasing ethanol 543 concentrations ( $50 \%, 70 \%, 100 \%$ in water) was performed and samples were embedded

544 on glas slides in Euparal. Expression profiles of eco genes under the different treatments 545 were analyzed under the microscope.

547 Immunohistochemistry. Immunostainging was performed using standard procedures (90):

548 animals were relaxed in $2 \%$ urethan for $2 \mathrm{~min}$ on ice and fixed in $4 \%$ PFA over night at $4{ }^{\circ} \mathrm{C}$.

549 Fixative was removed with four washes in PBT (PBS $+0.1 \%$ Tween20) for 15 min, cell 550 membranes opened with PBS $+0.5 \%$ TritonX100 for $30 \mathrm{~min}$, and unspecific binding sites 551 blocked with PBT $+1 \%$ bovine serum albumin for $1 \mathrm{~h}$, everything done at room temperature.

552 The primary antibody was a polyclonal rabbit antibody raised against a $14 \mathrm{AA}$ fragment 553 (NSIKENMENFYPVE, AA 52-65, GeneScript, USA) of Eco1 and was incubated in PBT + $1 \%$ 554 bovine serum albumin, $10 \mu \mathrm{g} / \mathrm{ml}$ rabbit- $\alpha-E c 01-A B$ over night at $4{ }^{\circ} \mathrm{C}$. The primary antibody 555 was removed with four washes in PBT $+1 \%$ bovine serum albumin for 15 min at room 556 temperature. Secondary anitbody (goat-a-rabbit Alexa Flour 488 coupled, \#A11034; LOT 557 1670152, Life Technologies) was incubated at $1 \mu \mathrm{g} / \mathrm{ml}$ in PBT $+1 \%$ bovine serum albumin 558 and incubated for $2 \mathrm{~h}$ at room temperature, from this step on samples were kept in dark. 559 Secondary antibody was removed by four washes in PBS $+0.5 \%$ Tween $20,1 \%$ bovine 560 serum albumin for $15 \mathrm{~min}$ at room temperature. Actin cytoskeleton staining was performed 561 with rhodamine-phalloidin (\#P1951, Sigma) in PBT for $1 \mathrm{~h}$ at room temperature and 562 afterwards removed with four washes of PBS $+0.5 \%$ Tween $20,1 \%$ bovine serum albumin.

563 To stain the nucleus we incubated the samples with TO-PRO3 iodide AlexaFluor633 564 (\#T3605, LOT 23929W, Invitrogen) in PBS + 0.5 \% Tween20, 1 \% bovine serum albumin for $56510 \mathrm{~min}$ at room temperature. Afterwards samples were transferred onto glas slides, 566 embedded in Moviol and stored at $4{ }^{\circ} \mathrm{C}$ until analysis using a confocal laser scanning 567 microscope (TCS SP1, Leica)

569 Transplantation experiments. Rings of tissue right beneath the tentacle ring were excised 570 from donor animals and grafted into the $\sim 1 / 3$ of the body axis from head to foot of the 571 acceptor animal, using fishing strings and polypropylene tubes for fixation of the tissues. 
572 Grafts were grown together after 2-3 $\mathrm{h}$ and fishing strings were removed. The induction of

573 heads was assessed 2-3 days post transplantation using the fluorescent markers and a

574 binocular. Every form of head structure was evaluated as head, including a single tentacle, a

575 hypostome or a complete hypostome with an tentacle ring.

576

\section{Author contributions}

578 J. Taubenheim, S. Franzenburg, T. C. G. Bosch and S. Fraune. designed the experiments;

579 J. Taubenheim, M. Knop, D. Willoweit-Ohl, S. Franzenburg, and J. He conducted

580 experiments. J. Taubenheim, M. Knop and S. Fraune performed data analysis.

581 J. Taubenheim, T. C. G. Bosch and S. Fraune wrote the paper, all authors corrected final

582 version of the paper.

583

\section{Acknowledgement}

585 We greatly appreciate provision and microinjection of the Hydra embryos by Jörg Wittlieb.

586 We further thank Alexander Klimovich for help in the design of the antibodies and help with

587 the confocal microscopy. This work was funded by the German Research Foundation (DFG,

588 CRC1182). T.C.G. B. gratefully appreciates support from the Canadian Institute for

589 Advanced Research (CIFAR). 


\section{References}

591

592 1. McGlashan JK, Spencer R-J, Old JM (2012) Embryonic communication in the

593 nest: metabolic responses of reptilian embryos to developmental rates of

594 siblings. Proc R Soc B Biol Sci 279(1734):1709-1715.

595 2. Callier V, Nijhout HF (2011) Control of body size by oxygen supply reveals

596 size-dependent and size-independent mechanisms of molting and

597 metamorphosis. Proc Natl Acad Sci 108(35):14664-14669.

598 3. Zera AJ, Tiebel KC (1988) Brachypterizing effect of group rearing, juvenile 599

600

601

4. Ogawa A, Streit A, Antebi A, Sommer RJ (2009) A Conserved Endocrine

602

603

604

5. Shikuma NJ, Antoshechkin I, Medeiros JM, Pilhofer M, Newman DK (2016)

605

606

607 hormone III and methoprene in the wing-dimorphic cricket, Gryllus rubens. $J$ Insect Physiol 34(6):489-498.

608 6. West-Eberhard MJ (2003) Developmental plasticity and evolution (Oxford Mechanism Controls the Formation of Dauer and Infective Larvae in Nematodes. Curr Biol 19(1):67-71.

612 7. Gilbert SF, Bosch TCG, Ledón-Rettig C (2015) Eco-Evo-Devo: Developmental Stepwise metamorphosis of the tubeworm Hydroides elegans is mediated by a bacterial inducer and MAPK signaling. Proc Natl Acad Sci 113(36):1009710102.

8. Abouheif E, Favé MJ, Ibarrarán-Viniegra AS, Lesoway MP, Rafiqi AM, University Press) Available at: https://books.google.de/books? $\mathrm{id}=\mathrm{iBkQyA2PkxEC \& dq=Developmental+Plasticity+and+Evolution \& hl=de \& sourc}$ e=gbs_navlinks_s [Accessed April 25, 2019].

618 9. Ghosh SM, Testa ND, Shingleton AW (2013) Temperature-size rule is symbiosis and developmental plasticity as evolutionary agents. Nat Rev Genet 16(10):611-622.

621

10. Atkinson D (1994) Temperature and Organism Size-A Biological Law for Rajakumar R (2014) Eco-Evo-Devo: The time has come. Adv Exp Med Biol 781:107-125.

623 11. Gillooly JF, Charnov EL, West GB, Savage VM, Brown JH (2002) Effects of mediated by thermal plasticity of critical size in Drosophila melanogaster. Proc R Soc B Biol Sci 280(1760):20130174-20130174.

625

12. Bergmann C (1848) Über die Verhältnisse der Wärmeökonomie der Thiere zu 
AAAAcAAJ\&oi=fnd\&pg=PA3\&dq=Bergmann+1848\&ots $=Y k W T t F n a f 5 \&$ sig $=5 \mathrm{w}$ W6LvN-JR7V7g5L_Ewjhh8Fjws [Accessed April 29, 2019].

629 13. Li Q, Gong Z (2015) Cold-sensing regulates Drosophila growth through insulinproducing cells. Nat Commun 6:1-11.

631 14. Fraune S, Bosch TC (2010) Why bacteria matter in animal development and evolution. Bioessays 32(7):571-580.

15. Landmann F, Foster JM, Michalski ML, Slatko BE, Sullivan W (2014) Coevolution between an Endosymbiont and Its Nematode Host: Wolbachia Asymmetric Posterior Localization and AP Polarity Establishment. PLoS Negl Trop Dis 8(8):e3096.

16. Landmann F, Voronin D, Sullivan W, Taylor MJ (2011) Anti-filarial Activity of Antibiotic Therapy Is Due to Extensive Apoptosis after Wolbachia Depletion from Filarial Nematodes. PLoS Pathog 7(11):e1002351.

17. Montgomery MK, McFall-Ngai M (1994) Bacterial Symbionts Induce Host Organ Morphogenesis during Early Postembryonic Development of the Squid Euprymna Scolopes. Development 120(7):1719-1729.

18. De Vadder F, Grasset E, Holm LM, Karsenty G, Macpherson AJ, Olofsson LE, Bäckhed $F$ (2018) Gut microbiota regulates maturation of the adult enteric nervous system via enteric serotonin networks. Proc Natl Acad Sci U S A 115(25):6458-6463.

19. Hedgecock EM, Russell RL (1975) Normal and mutant thermotaxis in the nematode Caenorhabditis elegans. Proc Natl Acad Sci 72(10):4061-4065.

20. Kammenga JE, Doroszuk A, Riksen JAG, Hazendonk E, Spiridon L, Petrescu A-J, Tijsterman M, Plasterk RHA, Bakker J (2007) A Caenorhabditis elegans wild type defies the temperature-size rule owing to a single nucleotide polymorphism in tra-3. PLoS Genet 3(3):e34.

21. Okamoto N, Nishimura T (2015) Signaling from Glia and Cholinergic Neurons Controls Nutrient-Dependent Production of an Insulin-like Peptide for Drosophila Body Growth. Dev Cell 35(3):295-310.

22. Fujiwara M, Sengupta P, McIntire SL (2002) Regulation of body size and behavioral state of $\mathrm{C}$. elegans by sensory perception and the EGL-4 cGMPdependent protein kinase. Neuron 36(6):1091-102.

23. Sawala A, Gould AP (2017) The sex of specific neurons controls female body

24. Pietschke C, Treitz C, Forêt S, Schultze A, Künzel S, Tholey A, Bosch TCG, 
665

666

667

668

669

670

671

672

673

674

675

676

677

678

679

680

681

682

683

684

685

686

687

688

689

690

691

692

693

694

695

696

697

698

699

700

701

25. Fraune S, Anton-Erxleben F, Augustin R, Franzenburg S, Knop M, Schröder K, Willoweit-Ohl D, Bosch TCG (2015) Bacteria-bacteria interactions within the microbiota of the ancestral metazoan Hydra contribute to fungal resistance. ISME J 9(7). doi:10.1038/ismej.2014.239.

26. Franzenburg S, Walter J, Künzel S, Wang J, Baines JF, Bosch TCG, Fraune S (2013) Distinct antimicrobial peptide expression determines host speciesspecific bacterial associations. Proc Natl Acad Sci U S A 110(39). doi:10.1073/pnas.1304960110.

27. Mortzfeld BM, Taubenheim J, Fraune S, Klimovich AV, Bosch TCG (2018) Stem cell transcription factor FoxO controls microbiome resilience in hydra. Front Microbiol 9(APR). doi:10.3389/fmicb.2018.00629.

28. Fraune S, Bosch TCG (2007) Long-term maintenance of species-specific bacterial microbiota in the basal metazoan Hydra. Proc Natl Acad Sci U S A 104(32):13146-13151.

29. Mortzfeld BM, Taubenheim J, Klimovich A V., Fraune S, Rosenstiel P, Bosch TCG (2019) Temperature and insulin signaling regulate body size in Hydra by the Wnt and TGF-beta pathways. Nat Commun 10(1):3257.

30. Bosch TCG (2007) Why polyps regenerate and we don't: Towards a cellular and molecular framework for Hydra regeneration. Dev Biol 303(2):421-433.

31. Field KG, Olsen GJ, Lane DJ, Giovannoni SJ, Ghiselin MT, Raff EC, Pace NR, Raff RA (1988) Molecular Phylogeny of the Animal Kingdom. Science (80- ) 239(2):748-753.

32. Campbell RD (1967) Tissue dynamics of steady state growth in Hydra littoralis. Dev Biol 15(5):487-502.

33. Campbell RD (1967) Tissue dynamics of steady state growth inHydra littoralis. II. Patterns of tissue movement. J Morphol 121(1):19-28.

34. Campbell RD (1967) Tissue dynamics of steady state growth inhydra littoralis. III. Behavior of specific cell types during tissue movements. J Exp Zool 164(3):379-391.

35. Holstein TW, Hobmayer E, David CN (1991) Pattern of epithelial cell cycling in hydra. Dev Biol 148(2):602-611.

36. Hobmayer B, Rentzsch F, Kuhn K, Happel CM, von Laue CC, Snyder P, Rothbächer U, Holstein TW (2000) WNT signalling molecules act in axis formation in the diploblastic metazoan Hydra. Nature 407(6801):186-9.

37. Lengfeld T, Watanabe H, Simakov O, Lindgens D, Gee L, Law L, Schmidt HA, Özbek S, Bode H, Holstein TW (2009) Multiple Wnts are involved in Hydra organizer formation and regeneration. Dev Biol 330(1):186-199. 
38. Gee L, Hartig J, Law L, Wittlieb J, Khalturin K, Bosch TCG, Bode HR (2010) beta-catenin plays a central role in setting up the head organizer in hydra. Dev Biol 340(1):116-24.

39. MacWilliams HK (1983) Hydra transplantation phenomena and the mechanism of Hydra head regeneration. Dev Biol 96(1):217-238.

40. Browne EN (1909) The production of new hydranths in Hydra by the insertion of small grafts. J Exp Zool 7(1):1-23.

41. Turing A (1952) The chemical basis of morphogenesis. Philos Trans $R$ Soc Lond B Biol Sci 237(641):37-72.

42. Gierer A, Meinhardt $H$ (1972) A theory of biological pattern formation. Kybernetik 12(1):30-39.

43. Broun M, Gee L, Reinhardt B, Bode HR (2005) Formation of the head organizer in hydra involves the canonical Wnt pathway. Development 132(12):2907-2916.

44. Klimovich A, Rehm A, Wittlieb J, Herbst E-M, Benavente R, Bosch TCG (2018) Non-senescent Hydra tolerates severe disturbances in the nuclear lamina. Aging (Albany NY) 10(5):951-972.

45. Bosch TCG, Adamska M, Augustin R, Domazet-Loso T, Foret S, Fraune S, Funayama N, Grasis J, Hamada M, Hatta M, et al. (2014) How do environmental factors influence life cycles and development? An experimental framework for early-diverging metazoans. Bioessays 36(12):1185-94.

46. Boehm A-M, Rosenstiel P, Bosch TCG (2013) Stem cells and aging from a quasi-immortal point of view. BioEssays 35(11):994-1003.

47. Galliot B, Buzgariu W, Schenkelaars Q, Wenger $Y$ (2018) Non-developmental dimensions of adult regeneration in Hydra. Int J Dev Biol 62(6-7-8):373-381.

48. Gufler S, Artes B, Bielen H, Krainer I, Eder M-K, Falschlunger J, Bollmann A, Ostermann T, Valovka T, Hartl M, et al. (2018) $\beta$-Catenin acts in a positionindependent regeneration response in the simple eumetazoan Hydra. Dev Biol 433(2):310-323.

49. Bisbee JW (1973) Size determination in Hydra: The roles of growth and budding. Development 30(1).

50. Otto JJ, Campbell RD (1977) Tissue economics of hydra: regulation of cell cycle, animal size and development by controlled feeding rates. J Cell Sci 28(1).

51. Leost M, Schultz C, Link A, Wu YZ, Biernat J, Mandelkow EM, Bibb JA, Snyder GL, Greengard P, Zaharevitz DW, et al. (2000) Paullones are potent inhibitors 
of glycogen synthase kinase-3beta and cyclin-dependent kinase 5/p25. Eur J Biochem 267(19):5983-94.

740

741

742

743

744

745

746

747

748

749

750

751

752

753

754

755

756

757

758

759

760

761

762

763

764

765

766

767

768

769

770

771

772

773

774

52. Franzenburg S, Fraune S, Kunzel S, Baines JF, Domazet-Loso T, Bosch TCG (2012) MyD88-deficient Hydra reveal an ancient function of TLR signaling in sensing bacterial colonizers. Proc Natl Acad Sci 109(47):19374-19379.

53. Khalturin K, Hemmrich G, Fraune S, Augustin R, Bosch TCG (2009) More than just orphans: are taxonomically-restricted genes important in evolution? Trends Genet 25(9):404-413.

54. Tautz D, Domazet-Lošo T (2011) The evolutionary origin of orphan genes. Nat Rev Genet 12(10):692-702.

55. Turing AM (1952) The Chemical Basis of Morphogenesis. Philos Trans $R$ Soc B Biol Sci 237(641):37-72.

56. Meinhardt H, Gierer A (1974) Applications of a theory of biological pattern formation based on lateral inhibition. J Cell Sci 15(2):321-46.

57. Greber MJ, David CN, Holstein TW (1992) A quantitative method for separation of living Hydra cells. Roux's Arch Dev Biol 201(5):296-300.

58. MacWilliams HK (1983) Hydra transplantation phenomena and the mechanism of Hydra head regeneration. II. Properties of the head activation. Dev Biol 96(1):239-57.

59. MacWilliams HK (1983) Hydra transplantation phenomena and the mechanism of Hydra head regeneration. I. Properties of the head inhibition. Dev Biol 96(1):217-238.

60. Takano J, Sugiyama T (1983) Genetic analysis of developmental mechanisms in hydra. VIII. Head-activation and head-inhibition potentials of a slow-budding strain (L4). J Embryol Exp Morphol 78(2):141-68.

61. Holstein TW (2012) The evolution of the Wnt pathway. Cold Spring Harb Perspect Biol 4(7):a007922.

62. Watanabe H, Schmidt HA, Kuhn A, Höger SK, Kocagöz Y, Laumann-Lipp N, Özbek S, Holstein TW (2014) Nodal signalling determines biradial asymmetry in Hydra. Nature 515(7525):112-115.

63. Khalturin K, Anton-Erxleben F, Milde S, Plötz C, Wittlieb J, Hemmrich G, Bosch TCG (2007) Transgenic stem cells in Hydra reveal an early evolutionary origin for key elements controlling self-renewal and differentiation. Dev Biol 309(1):32-44.

64. Hartl M, Glasauer S, Gufler S, Raffeiner A, Puglisi K, Breuker K, Bister K, Hobmayer B (2019) Differential regulation of myc homologs by Wnt/ $\beta$-Catenin signaling in the early metazoan Hydra. FEBS J 286(12):2295-2310. 
65. Guder C, Pinho S, Nacak TG, Schmidt HA, Hobmayer B, Niehrs C, Holstein TW (2006) An ancient Wnt-dickkopf antagonism in Hydra. Development 133(5):901-911.

66. Augustin R, Franke A, Khalturin K, Kiko R, Siebert S, Hemmrich G, Bosch TCG (2006) Dickkopf related genes are components of the positional value gradient in Hydra. Dev Biol 296(1):62-70.

67. Vogg MC, Beccari L, Iglesias Ollé L, Rampon C, Vriz S, Perruchoud C, Wenger Y, Galliot B (2019) An evolutionarily-conserved Wnt3/ $\beta$-catenin/Sp5 feedback loop restricts head organizer activity in Hydra. Nat Commun 10(1):312.

68. Lommel M, Strompen J, Hellewell AL, Balasubramanian GP, Christofidou ED, Thomson AR, Boyle AL, Woolfson DN, Puglisi K, Hartl M, et al. (2018) Hydra Mesoglea Proteome Identifies Thrombospondin as a Conserved Component Active in Head Organizer Restriction. Sci Rep 8(1):1-18.

69. Reddy PC, Gungi A, Ubhe S, Pradhan SJ, Kolte A, Galande S (2019) Molecular signature of an ancient organizer regulated by $\mathrm{Wnt} / \mathrm{\beta}$-catenin signalling during primary body axis patterning in Hydra. Commun Biol 2(1):111.

70. Cardenas M, Fabila Y V., Yum S, Cerbon J, Böhmer FD, Wetzker R, Fujisawa T, Bosch TCG, Salgado LM (2000) Selective protein kinase inhibitors block head-specific differentiation in hydra. Cell Signal 12(9-10):649-658.

71. Fabila Y, Navarro L, Fujisawa T, Bode HR, Salgado LM (2002) Selective inhibition of protein kinases blocks the formation of a new axis, the beginning of budding, in Hydra. Mech Dev 119(2):157-164.

72. Schüler A, Schmitz G, Reft A, Özbek S, Thurm U, Bornberg-Bauer E (2015) The Rise and Fall of TRP-N, an Ancient Family of Mechanogated Ion Channels, in Metazoa. Genome Biol Evol 7(6):1713-1727.

73. Malafoglia V, Traversetti L, Del Grosso F, Scalici M, Lauro F, Russo V, Persichini T, Salvemini D, Mollace V, Fini M, et al. (2016) Transient Receptor Potential Melastatin-3 (TRPM3) Mediates Nociceptive-Like Responses in Hydra vulgaris. PLoS One 11(3):e0151386.

74. Cheesman SE, Neal JT, Mittge E, Seredick BM, Guillemin K (2011) Epithelial cell proliferation in the developing zebrafish intestine is regulated by the Wnt pathway and microbial signaling via Myd88. Proc Natl Acad Sci 108(Supplement_1):4570-4577.

75. Franco AT, Israel DA, Washington MK, Krishna U, Fox JG, Rogers AB, Neish AS, Collier-Hyams L, Perez-Perez GI, Hatakeyama M, et al. (2005) Activation of $\beta$-catenin by carcinogenic Helicobacter pylori. Proc Natl Acad Sci U S A 102(30):10646-10651. 
813

814

815

816

817

818

819

820

821

822

823

824

825

826

827

828

829

830

831

832

833

834

835

836

837

838

839

840

841

842

843

844

845

846

847

848

849

76. Murata-Kamiya N, Kurashima Y, Teishikata Y, Yamahashi Y, Saito Y, Higashi $\mathrm{H}$, Aburatani H, Akiyama T, Peek RM, Azuma T, et al. (2007) Helicobacter pylori CagA interacts with E-cadherin and deregulates the $\beta$-catenin signal that promotes intestinal transdifferentiation in gastric epithelial cells. Oncogene 26(32):4617-4626.

77. Heath-Pagliuso S, Rogers WJ, Tullis K, Seidel SD, Cenijn PH, Brouwer A, Denison MS (1998) Activation of the Ah Receptor by Tryptophan and Tryptophan Metabolites ${ }^{\dagger}$. Biochemistry 37(33):11508-11515.

78. Kawajiri K, Kobayashi Y, Ohtake F, Ikuta T, Matsushima Y, Mimura J, Pettersson S, Pollenz RS, Sakaki T, Hirokawa T, et al. (2009) Aryl hydrocarbon receptor suppresses intestinal carcinogenesis in ApcMin/+ mice with natural ligands. Proc Natl Acad Sci 106(32):13481-13486.

79. Li L, Zheng W, Zhu Y, Ye H, Tang B, Arendsee ZW, Jones D, Li R, Ortiz D, Zhao X, et al. (2015) QQS orphan gene regulates carbon and nitrogen partitioning across species via NF-YC interactions. Proc Natl Acad Sci 112(47):14734-14739.

80. Li L, Foster CM, Gan Q, Nettleton D, James MG, Myers AM, Wurtele ES (2009) Identification of the novel protein QQS as a component of the starch metabolic network in Arabidopsis leaves. Plant J 58(3):485-498.

81. Santos ME, Le Bouquin A, Crumière AJJ, Khila A (2017) Taxon-restricted genes at the origin of a novel trait allowing access to a new environment. Science (80- ) 358(6361):386-390.

82. Khalturin K, Anton-Erxleben F, Sassmann S, Wittlieb J, Hemmrich G, Bosch TC (2008) A novel gene family controls species-specific morphological traits in Hydra. PLoS Biol 6(11):e278.

83. Sackton TB, Lazzaro BP, Schlenke TA, Evans JD, Hultmark D, Clark AG (2007) Dynamic evolution of the innate immune system in Drosophila. Nat Genet 39(12):1461-1468.

84. Colbourne JK, Pfrender ME, Gilbert D, Thomas WK, Tucker A, Oakley TH, Tokishita S, Aerts A, Arnold GJ, Basu MK, et al. (2011) The Ecoresponsive Genome of Daphnia pulex. Science (80- ) 331(6017):555-561.

85. Kuo C-H, Kissinger JC (2008) Consistent and contrasting properties of lineagespecific genes in the apicomplexan parasites Plasmodium and Theileria. BMC Evol Biol 8(1):108.

86. Schwentner M, Bosch TCG (2015) Revisiting the age, evolutionary history and species level diversity of the genus Hydra (Cnidaria: Hydrozoa). Mol Phylogenet Evol 91:41-55. 
850 87. Hemmrich G, Anokhin B, Zacharias H, Bosch TCG (2007) Molecular phylogenetics in Hydra, a classical model in evolutionary developmental biology. Mol Phylogenet Evol 44(1):281-290.

853 88. Pfaffl MW (2001) A new mathematical model for relative quantification in real854 time RT-PCR. Nucleic Acids Res 29(9):e45.

855 89. Grens A, Gee L, Fisher DA, Bode HR (1996) CnNK-2,an NK-2 homeobox gene, has a role in patterning the basal end of the axis in Hydra. Dev Biol 180(2):473-488.

858 90. Engel U, Ozbek S, Streitwolf-Engel R, Petri B, Lottspeich F, Holstein TW (2002) Nowa, a novel protein with minicollagen Cys-rich domains, is involved in nematocyst formation in Hydra. J Cell Sci 115(Pt 20):3923-3934. 


\section{Supplements}

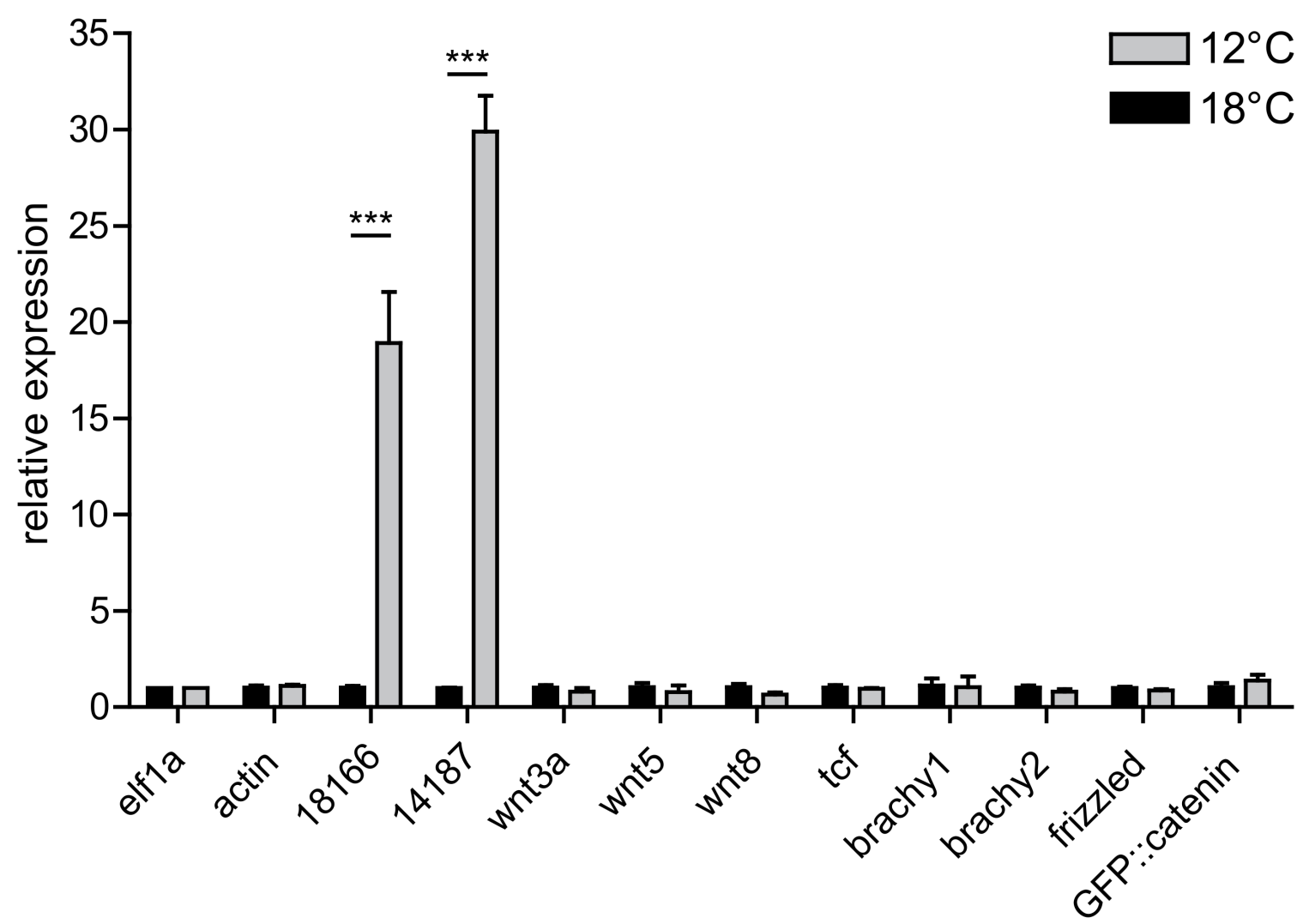

Supplementary Figure 1: The temperature shift does not change the expression of Wnt pathway components. Temperature change has no impact on the expression of Wnt3a, Wnt5, Wnt8, TCF, Frizzled, head formation associated hox genes (brachyury 1 and 2 ) or the expression of the $\beta$-catenin OE construct, but is associated with an 20 to 30 fold up regulation of the eco genes ( $\mathrm{n}$ $=3$, Two-way ANOVA, Bonferroni posttests, ${ }^{* * *} p<0.001$ ). 


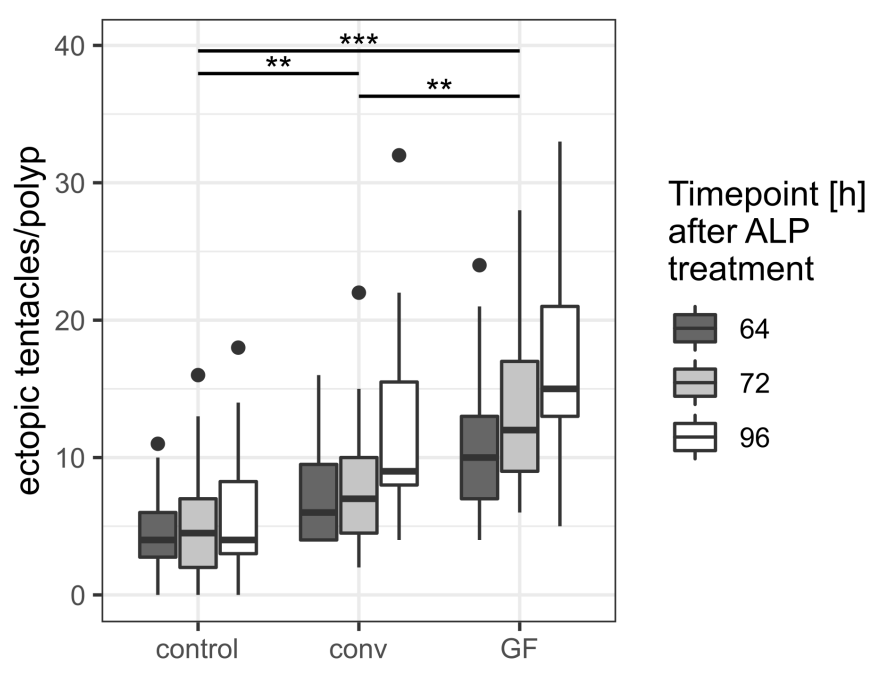

Supplementary Figure 2: Ectopic tentacle formation after ALP is dependent on the bacterial colonization in Hydra. Treatment of germ-free Hydra polyps with ALP leads to an increase of ectopic tentacle formation, compared to control and conventionalized animals (recolonized for 4 days prior treatment). The conventionalized and the germ-free animals show some dynamics in tentacle formation, with most tentacles formed $96 \mathrm{~h}$ after ALP treatment. Conventionalized Hydra represent an intermediate state for tentacle formation after ALP treatment, but is able to mitigate the effect in germfree animals. $n=15$ for conv and GF, 20 for control, fitted generalized linear model with poisson log link function for each time point individually. Multiple comparison for the treatment factor with generalized linear hypothesis testing ( $R$ package multcomp) and $p$-values corrected with BenjaminiHochberg procedure. Asterisks code for the highest $p$-value in the comparisons at the different time points: ${ }^{* * *} p<0.001,{ }^{* *} p<0.01$. See Supplementary Table 1 for test statistics.

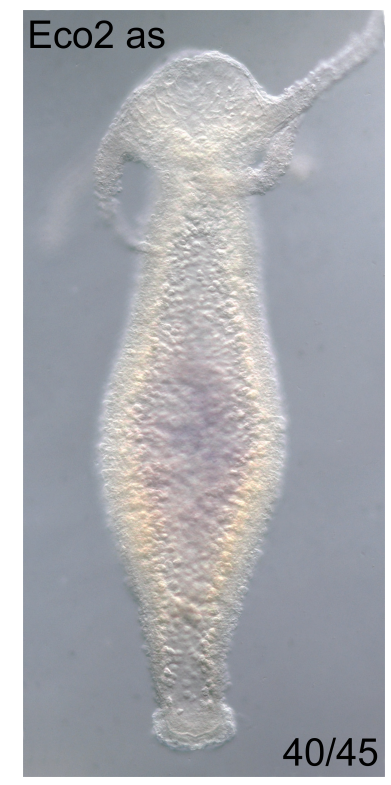

Supplementary_Figure 3: Missing expression signal for eco2 gene expression after in-situ hybridization. Most of the animals showed no signal after in-situ hybridization with an anti-sense probe (40/45). The low fraction of stained animals is caused by the low eco2 signal at $18^{\circ} \mathrm{C}$ rearing temperature. 
A

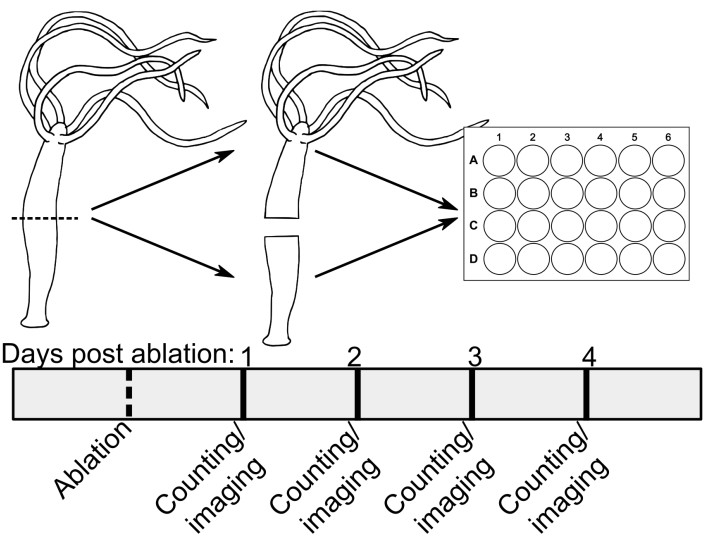

C Head regeneration
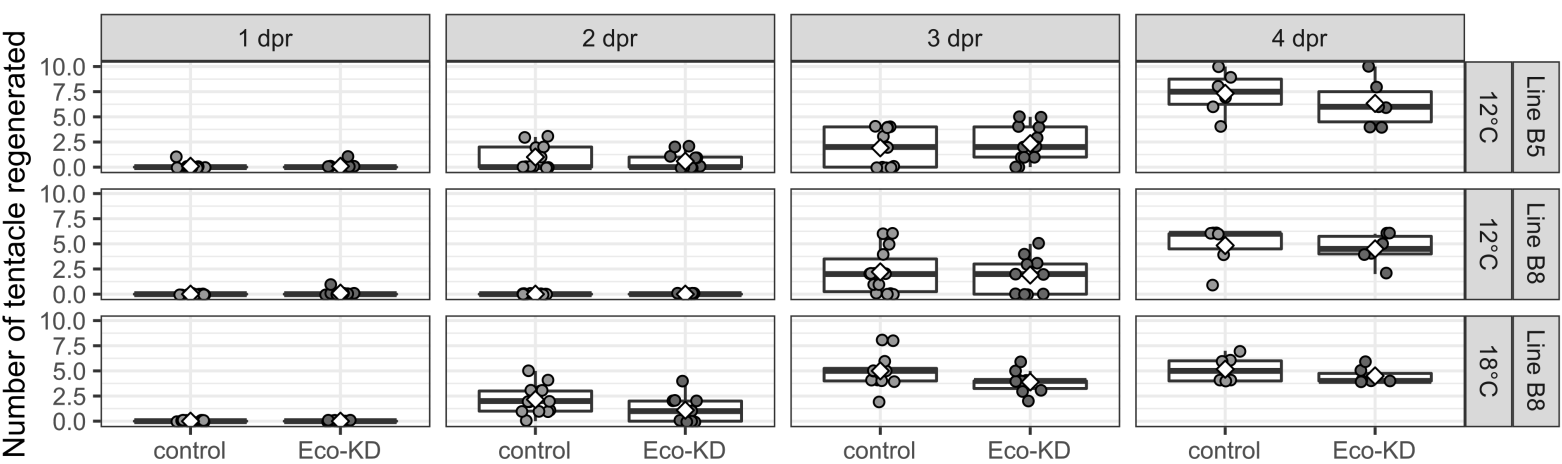

D Foot regeneration
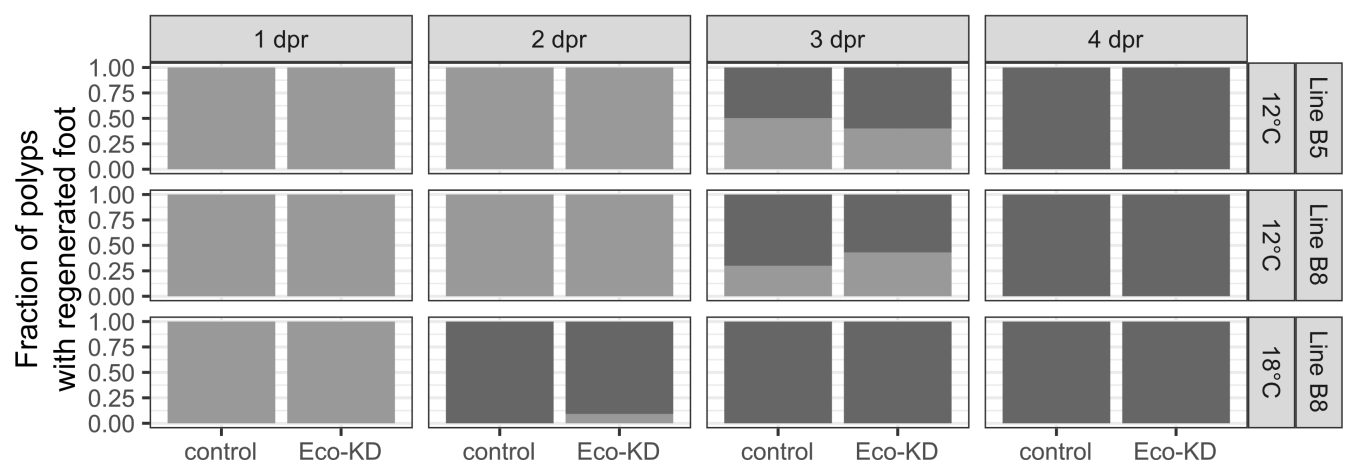

Supplementary Figure 4: eco expression does not influence the regeneration processes in Hydra. (A) To test for a role of eco genes in pattern formation during regeneration, animals were cut in half and each piece was placed individually in a 24-well plate. The regenerating pieces were observed for 3-4 days, counting emerging tentacles and foots every day. (B) The timing of the head regeneration (first appearance of a tentacle) was not altered by the knock-down of the eco genes in $12^{\circ} \mathrm{C}$ as well as $18^{\circ} \mathrm{C}$ (Wilcoxon-test, with Benjamini-Hochberg correction, $\mathrm{n}=11,12,13,9,13,10$ polyps for each group, following the order of the graphic left to right). (C) Number of tentacles at different time points of regeneration was indifferent between Eco-KD and control animals (t-test @dpa 3 and 4, with Benjamini-Hochberg correction, $n=6-14$ polyps for each group). (D) The fraction of polyps regenerating a foot after ablation was not changed in an Eco-KD background (Fisher's-exact test @dpa $=3\left(12^{\circ} \mathrm{C}\right)$ or $2\left(18^{\circ} \mathrm{C}\right), \mathrm{n}=6-14$ polyps for each group).

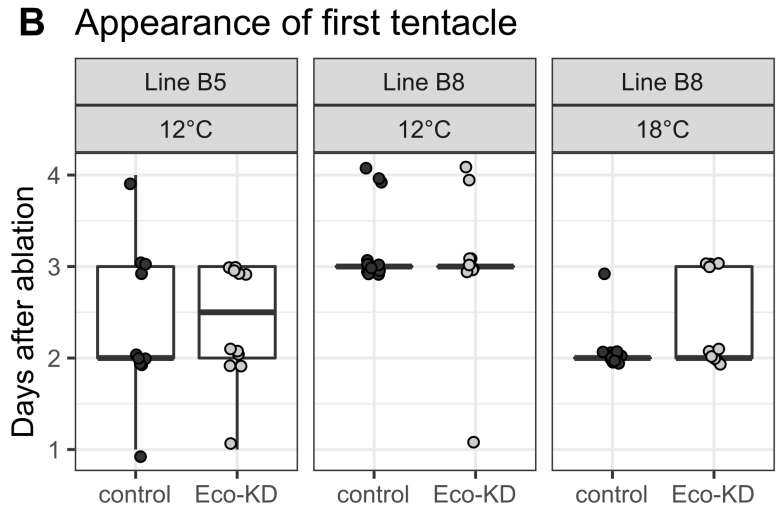




\section{ALP effect on eco genes}

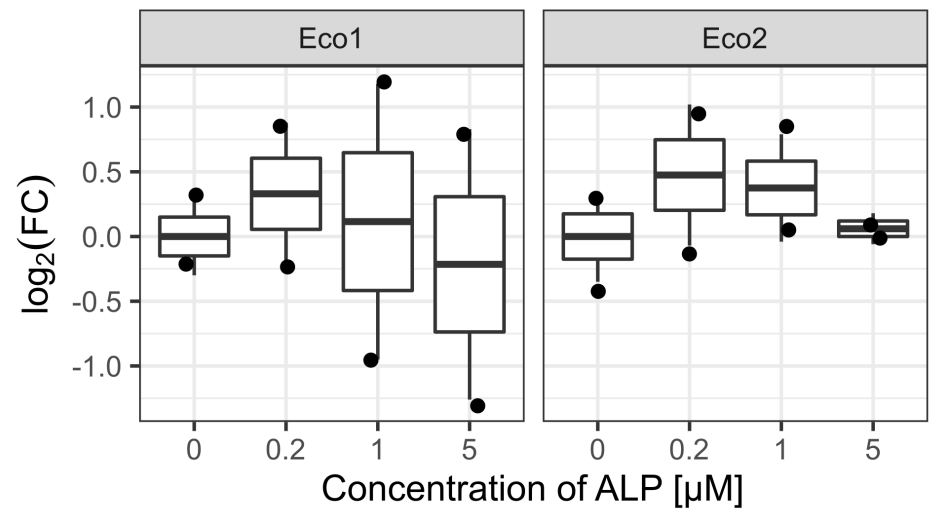

Supplementary Figure 5: ALP treatment does not result in expression changes of eco genes. Animals treated with different concentrations of ALP for $24 \mathrm{~h}$ showed now significant difference in the gene expression for eco genes (ANOVA, gene corrected $p=0.532$, see Supplementary Table $4)$.

\section{Figure legends}

Figure 1: Wnt-signaling is temperature dependent. (A) Animals reared at $12{ }^{\circ} \mathrm{C}$ and $18{ }^{\circ} \mathrm{C}$ were treated with ALP for $24 \mathrm{~h}$, before assessment of ectopic tentacle formation after $96 \mathrm{~h}$. (B) Lower temperature leads to fewer ectopic tentacle formation after ALP treatment. (t-test, $\left.n=12,{ }^{*} p<0.05\right)(C-F)$ Constitutive active Wnt signaling in $\beta$-catenin OE animals causes multiple heads/body axes at $18^{\circ} \mathrm{C}$, while the severity of the phenotype was subdued when animals were reared at $12{ }^{\circ} \mathrm{C}$. (G) The number of heads produced by the $\beta$-catenin OE animals is reversible and depends on the rearing temperature, where surrounding temperatures of $12{ }^{\circ} \mathrm{C}$ resulted in fewer heads per polyp $(n=10)$.

Figure 2: Wnt-signaling is dependent on microbial colonization. (A) Animals were ALP treated for $24 \mathrm{~h}$ and number of generated ectopic tentacles were assessed $96 \mathrm{~h}$ after treatment, comparing the treatment outcome of germfree (GF) and normally colonized animals (control). (b-d) Ectopic tentacle formation is increased when colonizing bacteria were removed, suggesting a role of microbial colonization in pattern formation in Hydra (Mann Whitney $U$ test, $n=58,{ }^{* * *} p<0.0001$ ). with colonized ones, and transcriptomic data, comparing animals at different rearing temperatures, revealed two candidate genes with common regulation upon environmental changes: eco1 and eco2. (b) Sequence analysis of the candidate genes revealed a paralogous relationship between the two genes and a secretion signal peptide, without any domain structure. (c-d) qRT-PCR assessment of eco gene expression in germfree animals and upon temperature shift confirms down regulation of eco1 and eco2 expression at higher rearing temperatures ( $n=3$, Two-way ANOVA, Bonferroni posttests, ${ }^{* *} p<0.01,{ }^{* * *} p<0.001$ ) and in disturbed microbiome conditions ( $\mathrm{n}=3$, Two-way ANOVA, Bonferroni posttests, * $\left.p<0.05,{ }^{* *} p<0.01,{ }^{* * *} p<0.001\right)$. (e-h) eco genes were expressed in the foot and lower third of the animals at $18{ }^{\circ} \mathrm{C}$ rearing temperature, but the expression domain expands to the body column and parts of the head at $12{ }^{\circ} \mathrm{C}$. (i-j) Immunohistochemistry with a polyclonal antibody 
raised against a fragment of Eco1 (underlined in b) show the production of the peptides in the ectodermal epithelium and packaging in vesicles localized in the apical part of the cells, which suggests a secretion of the peptide.

Figure 4: Expression dynamics of eco genes were a long term adaptation to changing microbial state or rearing temperatures. (A) eco gene expression was reestablished by recolonization with bacteria after $14 \mathrm{~d}$, but did not reach normal levels after only $8 \mathrm{~d}$ recolonization ( $n=3$, Two-way ANOVA, Bonferroni posttests, ${ }^{*} p<0.05,{ }^{* *} p<0.01,{ }^{* * *}$ $p<0.001$ ) (B) Recolonization with the main colonizer Curvibacter sp. alone was sufficient to alleviate the expression suppression of eco genes after $14 \mathrm{~d}$ of colonization. ( $n=4$, Two-way ANOVA, Bonferroni posttests, $\left.{ }^{*} p<0.05,{ }^{* * *} p<0.001\right)(C)$ eco gene expression changes were established within 14-16 d upon rearing temperature shifts from $18{ }^{\circ} \mathrm{C}$ to $12{ }^{\circ} \mathrm{C}$ and vice versa. (D) Microbial colonization state and rearing temperature were independent inputs for the expression regulation of eco genes. Gene expression is up regulated upon temperature shifts from $18^{\circ} \mathrm{C}$ to $12^{\circ} \mathrm{C}$, independent of colonization state of the animals. (E, F) The graphic displays effect size cleaned of overlaying variances. (E) The expression of eco genes increases within 14 days after reduction of rearing temperature, independent of the colonization status of the genes (ANOVA, $p=8.16 \mathrm{E}-9$ for temperature, $p=6.99 \mathrm{E}-6$ for temperature-time interaction, see Supplementary Table 3). (F) Removing bacteria from Hydra reduces expression of eco genes independent of temperature (ANOVA, $p=0.0557$ for colonization, $p=0.20$ for colonization-temperature interaction, see Supplementary Table 3).

Figure 5: Knockdown of eco genes results in increased Wnt signaling. (a) Eco-hairpin construct for generation of transgenic Hydra (as, antisense; s, sense; TAA, stop codon; P, promoter; $\mathrm{T}$, terminator) (b, c) Whole mount in situ hybridization of eco1 expression in Eco$\mathrm{KD}$ (b) and control (c) animals. (d) eco1 and eco2 expression in two transgenic lines (B8 and

$925 \mathrm{B5})$ at $12{ }^{\circ} \mathrm{C}$ and $18{ }^{\circ} \mathrm{C}\left(\mathrm{n}=3\right.$, Two-way ANOVA, Bonferroni posttests, $\left.{ }^{* * *} \mathrm{p}<0.001\right)(\mathrm{e}-\mathrm{f})$ Treating Eco1-KD animals with ALP revealed an increased potential to form ectopic tentacles, indicating a higher Wnt signaling activity. (f) The number of heads formed after transplantation of near head tissue into the body axis of an acceptor polyp serves as a readout for the head inhibition potential, which is governed by the inhibition of the Wnt signaling. (g-h) Control (unlabeled) and Eco-KD (GFP labeled) animals served as acceptor polyps for head tissues from wild type (dsRed labeled) animals to assess the head inhibition potential under disturbed eco expression. (i) Eco-KD polyps showed a reduced head inhibition potential, indicating an impaired Wnt inhibition in these animals. $n=75, p=0.0085$, Fisher's exact test.

Figure 6: Eco peptides are environmentally triggered inhibitors of Wnt signaling. Microbial colonization and low temperature are independent inputs for Eco peptides and are able to induce its transcription. Eco peptides are synthesized as small peptides, packed into vesicles and secreted into extracellular matrix of the ectoderm. By an unknown mechanism

940 Eco peptides are recognized and the Wnt signaling is inhibited. The inhibition takes place at 941 the level of $\beta$-catenin stabilization or the expression of Wnt target genes as Eco expression were able to inhibit activation of the pathway at the GSK-3 $\beta$ level. 
947 expression of the $\beta$-catenin OE construct, but is associated with an 20 to 30 fold up 948 regulation of the eco genes ( $n=3$, Two-way ANOVA, Bonferroni posttests, $\left.{ }^{* * *} p<0.001\right)$.

Supplementary Figure 2: Ectopic tentacle formation after ALP is dependent on the increase of ectopic tentacle formation, compared to control and conventionalized animals (recolonized for 4 days prior treatment). The conventionalized and the germ-free animals show some dynamics in tentacle formation, with most tentacles formed $96 \mathrm{~h}$ after ALP treatment. Conventionalized Hydra represent an intermediate state for tentacle formation after ALP treatment, but is able to mitigate the effect in germ-free animals. $n=15$ for conv and GF, 20 for control, fitted generalized linear model with poisson log link function for each time point individually. Multiple comparison for treatment factor with generalized linear hypothesis testing ( $R$ package multcomp) and $p$-values corrected with Benjamini-Hochberg procedure. Asterisks code $f$ or the highest $p$-value in the comparisons at the different timepoints: ${ }^{* * *} p<0.001,{ }^{* *} p<0.01$. See Supplementary Table 1 for test statistics.

Supplementary Figure 3: Missing expression signal for eco2 gene expression after insitu hybridization. Most of the animals showed no signal after in-situ hybridization with an anti-sense probe. The low fraction of stained animals is caused by the low eco2 signal at $18^{\circ} \mathrm{C}$ rearing temperature.

Supplementary Figure 4: Eco peptides are not involved in the regeneration process of Hydra. (A) To test for a role of eco genes in pattern formation during regeneration, animals were, randomized, cut in half and each piece was placed individually in a 24-well plate. The regenerating pieces were observed for 3-4 days, counting emerging tentacles and foots every day. (B) The timing of the head regeneration (first appearance of a tentacle) was not altered by the knock-down of the eco genes in $12^{\circ} \mathrm{C}$ as well as $18^{\circ} \mathrm{C}$ (Wilcoxon-test, with Benjamini-Hochberg correction, $n=9-13$ polyps for each group). (C) Number of tentacles at different time points of regeneration was indifferent between Eco-KD and control animals (ttest @dpa 3 and 4, with Benjamini-Hochberg correction, n=6-14 polyps for each group). (D) The fraction of polyps regenerating a foot after ablation was not changed in an Eco-KD background (Fisher's-exact test @dpa $=3\left(12^{\circ} \mathrm{C}\right)$ or $2\left(18^{\circ} \mathrm{C}\right), \mathrm{n}=6-14$ polyps for each group). 